\title{
Hydrothermal speleogenesis in carbonates and metasomatic silicites induced by subvolcanic intrusions: a case study from the Štiavnické vrchy Mountains, Slovakia
}

\author{
Pavel Bella ${ }^{1,2^{*}}$, L’udovít Gaál ${ }^{1}$, Vladimír Šucha ${ }^{3}$, Peter Koděra ${ }^{3}$, and Rastislav Milovský ${ }^{4}$ \\ ${ }^{1}$ State Nature Conservancy of the Slovak Republic, Slovak Caves Administration, Hodžova 11, 03101 Liptovský Mikuláš, Slovakia \\ ${ }^{2}$ Catholic University in Ružomberok, Pedagogical Faculty, Department of Geography, Hrabovská cesta 1, 03401 Ružomberok, Slovakia \\ ${ }^{3}$ Comenius University in Bratislava, Faculty of Natural Sciences, Department of Geology of Mineral Deposits, Mlynská dolina, 84215 Bratislava 4, Slovakia \\ ${ }^{4}$ Geological Institute, Slovak Academy of Sciences, Dumbierska cesta 1, 97401 Banská Bystrica, Slovakia
}

\begin{abstract}
Several caves of hydrothermal origin in crystalline limestones and metasomatic silicites were investigated in the central zone of the Štiavnica stratovolcano, Štiavnické vrchy Mountains, central Slovakia. Evidence of hydrothermal origin includes irregular spherical cave morphology sculptured by ascending thermal water, occurrence of large calcite crystals and hydrothermal alteration of host rocks, including hydrothermal clays. The early phases of speleogenesis in the crystalline limestone near Sklené Teplice Spa were caused by post-magmatic dissolution linked either to the emplacement of subvolcanic granodiorite intrusions during Late Badenian time or to the spatially associated Late Sarmatian epithermal system. Speleogenesis in metasomatic silicites in the Šobov area is related to hydrothermal processes associated with the pre-caldera stage of the Štiavnica stratovolcano in Late Badenian. Both localities are remarkable examples of hydrothermal speleogenesis associated with Miocene volcanic and magmatic activity in the Western Carpathians.
\end{abstract}

Keywords: hypogene karst; hydrothermal cave; post-magmatic dissolution; fluid inclusions; hydrothermal clays; stable isotopes; cavernous silicites; Central Slovakian Neogene Volcanic Field; Western Carpathians

Received 6 October 2014; Revised 14 October 2015; Accepted 14 October 2015

Citation: Bella P., Gaál L', Šucha V., Koděra P., and Milovský R., 2016. Hydrothermal speleogenesis in carbonates and metasomatic silicites induced by subvolcanic intrusions: a case study from the Štiavnické vrchy Mountains, Slovakia. International Journal of Speleology, 45 (1), 11-25. Tampa, FL (USA) ISSN 0392-6672 http://dx.doi.org/10.5038/1827-806X.45.1.1879

\section{INTRODUCTION}

Since 2010 we have been studying several caves formed in crystalline limestones and metasomatic silicites of the Štiavnické vrchy Mountains. These caves are located in the Inner Western Carpathians of central Slovakia (Fig. 1). This paper presents evidence that these caves are of hydrothermal origin, linked to several phases of the evolution of the Štiavnica stratovolcano. Hydrothermal caves belong to a larger group of caves of hypogene origin indentified on the basis of regional paleo-hydrogeological analysis, morphogenetic analysis of caves, cave sediments and minerals, and geochemical alteration of the host rock during hypogene speleogenesis (Dubljanskij, 1990; Dublyansky, 2000; Onac, 2002; Klimchouk, 2007, 2009; Spötl et al., 2009; and others). The caves described here contribute to a larger view of genetic variability of caves in Slovakia, which has a varied and complex geological setting. This study presents information about hydrothermal speleogenesis, including hydrothermal caves formed in metasomatic silicites.

\section{STUDIED CAVES AND THE SURROUDING AREA}

The area of investigation is near Banská Štiavnica, a well-known historic mining town included in the World Heritage list. The area is in the central part of the Štiavnica stratovolcano, the largest volcano in the Carpathian volcanic arc, which is part of the AlpineBalkan-Carpathian-Dinaride orogen (Konečný et al., 1995, 2001; Konečný \& Lexa, 2001; Lexa \& Koděra, 2010). The Miocene Štiavnica stratovolcano evolved during several stages from Badenian to Sarmatian, 15.0 to $10.7 \mathrm{Ma}$ (Chernyshev et al., 2013).

Early hydrothermal systems, related to emplacement of subvolcanic magmatic bodies in the pre-caldera stage of stratovolcanic evolution, formed mainly skarn and porphyry types of mineralisation. Vein mineralisation developed during later hydrothermal 


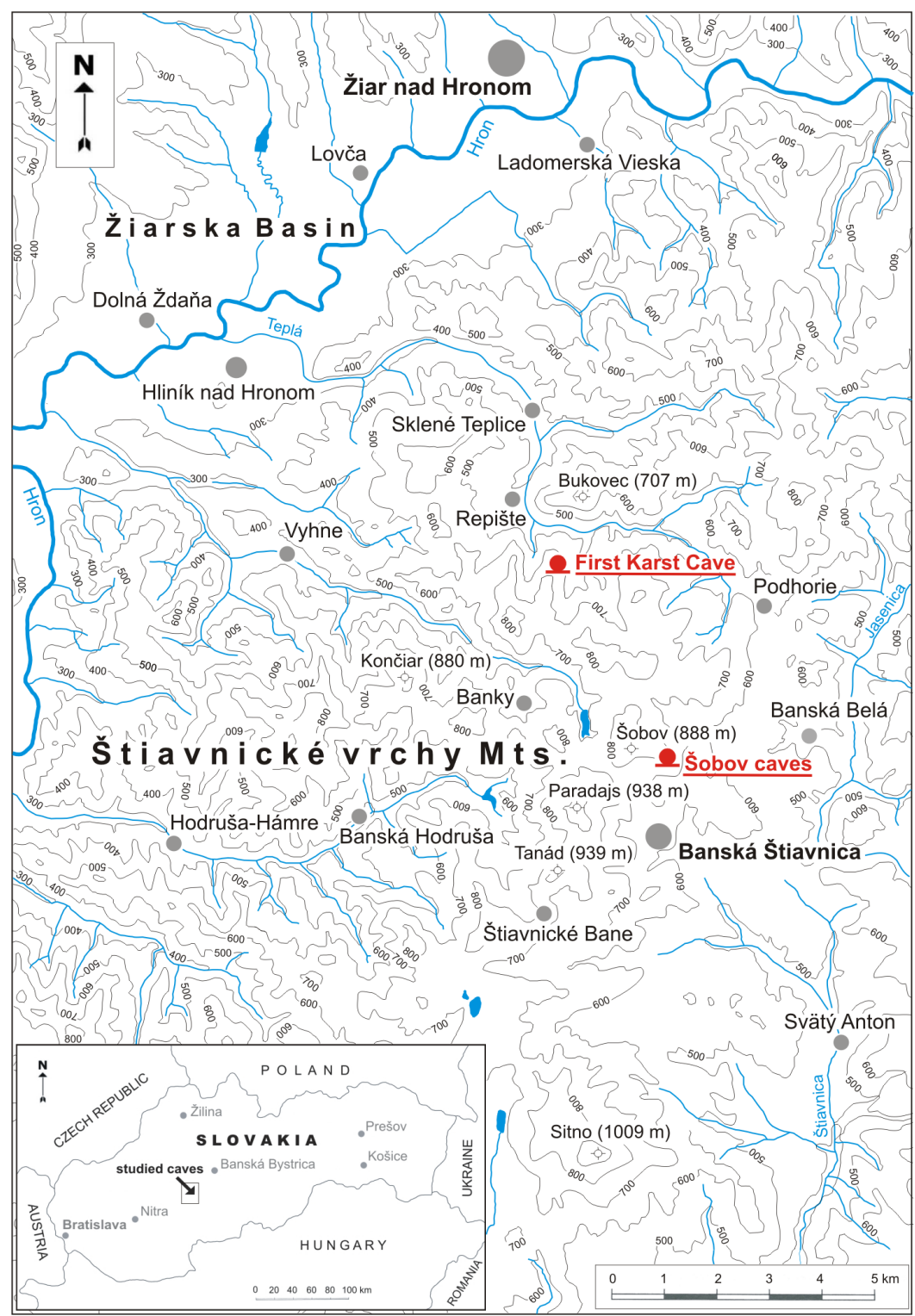

Fig. 1. Topographic map showing locations of studied caves in the Štiavnické vrchy Mountains.

events. Early type of veins developed during the precaldera stage and it is related to faults activated during subsidence of the caldera. Later type of veins developed in the post-caldera stage and they are related to faults associated with long-lasting horst uplift in the center of the caldera (Lexa et al., 1999; Lexa, 2001; Koderra et al., 2005). The mountains also host several lenses of Middle to Late Triassic carbonates that are locally metamorphosed to marble in contact with magmatic intrusions. The intrusions were emplaced during early stages of stratovolcano evolution (Konečný et al., 1998a,b) (Fig. 2).

The central zone of the Śtiavnica stratovolcano hosts caves in limestones and in andesites alterated to metasomatic silicites. Some caves have morphologic and mineralogic features of hypogene or hydrothermal origin.

\section{The First Karst Cave}

The First Karst Cave is located in the northern part of the Štiavnicke vrchy Mountains, about $3 \mathrm{~km}$ south of the Sklené Teplice Spa on the southwest side of the Teplá Stream Valley (Figs. 1 and 2). Middle Triassic limestones and dolomites crop out in the area (Konečný
\& Lexa, 1984; Konečný et al., 1998a,b). Based on our observations, these formations are Gutenstein dolomites and limestones and Steinalm limestones of the Hronicum Unit. Hydrothermal alteration occurred in each of these carbonate types, mainly along veins and stockworks. Steinalm limestones have been recrystallized to marble. The entrance shaft leading to the cave was dug by miners 200 to 300 years ago (Fig. 3A). A natural cave opening to the surface is unknown. Original cave passages and several smaller geode-like cavities were encountered at the base of the shaft. Two blind adits were dug along ore veins that intersect the cave. The southern adit is $20 \mathrm{~m}$ long, and the shorter eastern adit is $16 \mathrm{~m}$ long. The length of the cave and adits is approximately $100 \mathrm{~m}$ with a vertical range of $21 \mathrm{~m}$. The total depth from the entrance of the artificial shaft is $31 \mathrm{~m}$ (Ivan, 1991) (Figs. 3B and 3C). From the bottom of the shaft, the cave is a down-sloping passage with several stair steps. In the upper segment, the passage is mostly 2 to $2.5 \mathrm{~m}$ high and 3 to $4 \mathrm{~m}$ wide. The cave pattern is controlled by faults of $\mathrm{E}-\mathrm{W}$ and N-S directions (Bella et al., 2011a,b).

\section{The Šobov caves}

The Šobov Cave and the Šobov Chimney are located in the Šobov silicite quarry on the slope of the Malý Šobov Mount (836 m), approximately $1 \mathrm{~km}$ north of the town of Banská Štiavnica and $1 \mathrm{~km}$ south of the Banská Belá village (Figs. 1, 2, 4A, and 4B). Both caves were encountered when an exploratory mine adit was dug between $700 \mathrm{~m}$ and $715 \mathrm{~m}$ a.s.1. Here, metasomatic silicite is the result of acid leaching and silicification of andesite porphyries by magmatic fluids associated with the emplacement of a subvolcanic diorite intrusion during the precaldera stage of the Štiavnica stratovolcano in Early to Upper Badenian (Štohl et al., 1994; Lexa et al., 1999; Konečný \& Lexa, 2001; Lexa, 2001). The silicite is 95 to $98 \% \mathrm{SiO}_{2}$, with pyrite, anatase and rutile accessory minerals (Polák, 1961, 1963). Silicite is monotonous, composed almost entirely of fine-crystalline quartz accompanied by quartz veinlets (Oružinský, 1989). In the upper part of the quarry, the silicites contain rare caverns. Laterally, silicites grade in to argillites that contain sericite, pyrophylite and pyrite.

The Šobov Cave is a steeply inclined oval cavity with several ceiling hollows and small cupolas. Its origin was controlled by a WNW-oriented zone of weakness. The cave is $3.5 \mathrm{~m}$ long with a vertical extent of $3 \mathrm{~m}$ (Figs. 4C and 4D). The cavity is a fragment of a larger cave, but the upper part was destroyed during exploitation of the overlying quarry. The lower part of the cave was probably removed during excavation of the exploration mine adit (Bella et al., 2010, 2011a).

The Šobov Chimney, located $7 \mathrm{~m}$ south-east of Šobov Cave, is a vertical fissure cavity with a height of $6.3 \mathrm{~m}$ and width of 0.8 to $2.1 \mathrm{~m}$ (Fig. 4C). It is controlled 


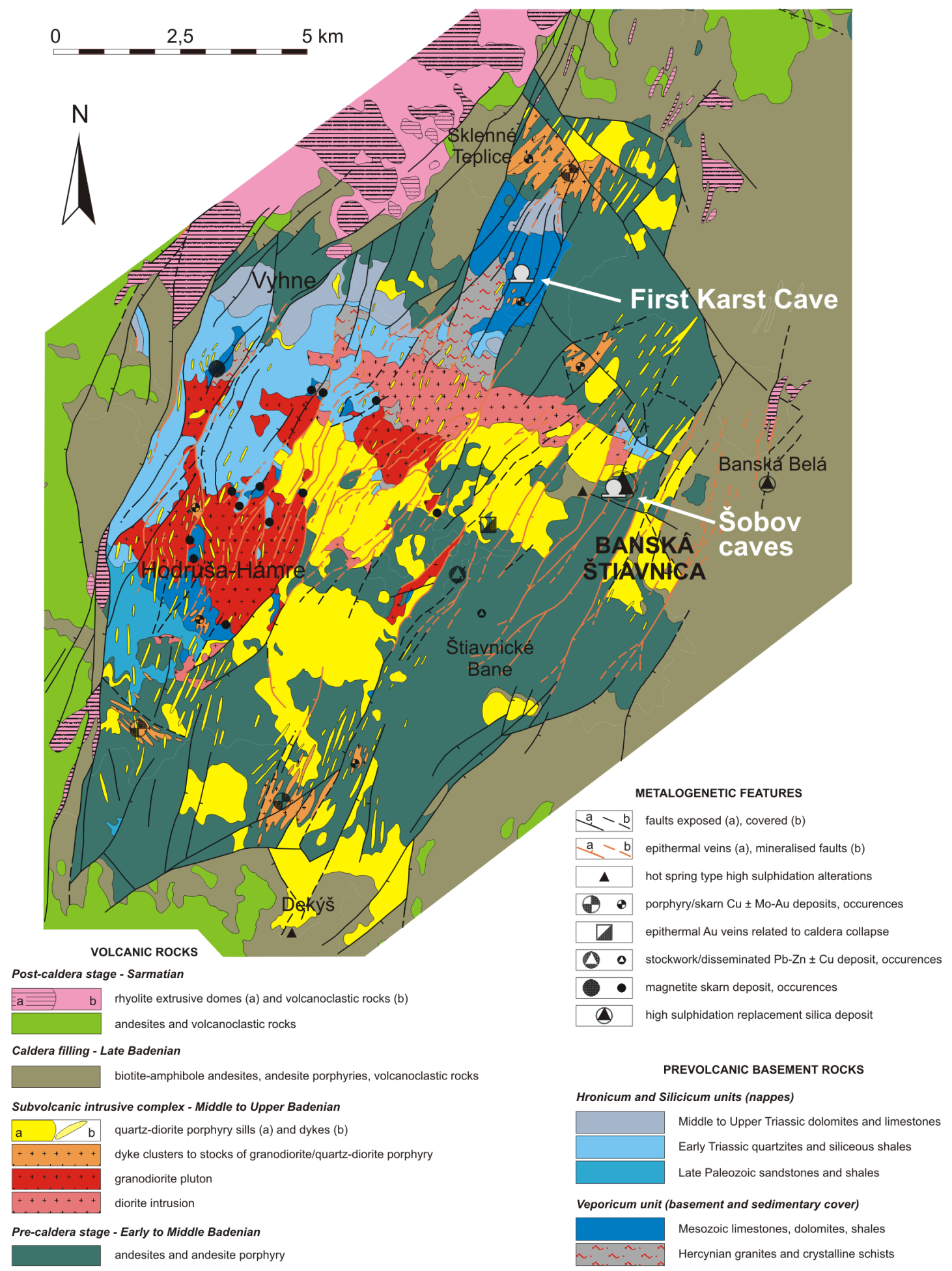

Fig. 2. Structural geological map of the resurgent horst in the center of the caldera in the central zone of the Štiavnica stratovolcano (after Lexa et al., 1999), with location of the studied caves.

by a steep to near-vertical NNE trending fault. Blind cupolas occur in the upper part of the cave, and small quartz crystals are found in the fissure exposed by the cave. Quartz crystals several centimeters in size are also known from other fissures in the metasomatic silicites of this quarry (Bella et al., 2010).

\section{METHODS}

Since 2010 our research in the Štiavnické vrchy Mountains has focused on documenting morphological and mineralogical evidence for the hydrothermal origin of the caves (Bella et al., 2010, $2011 \mathrm{a}, \mathrm{b})$. The orientations of structural-tectonic discontinuities in caves were compared to the pattern of faults and epithermal veins in the vicinity. Based on detailed observations and surveys, we have compared cave morphologies with indicators of hydrothermal speleogenesis (in sense of Bakalowicz et al., 1987; Ford \& Williams, 1989, 2007; Dubljanskij, 1990; Palmer, 1991, 2007; Dublyansky, 2000; Klimchouk, 2007; Audra et al., 2009b and others).

Sample sets of hard, altered and crumbled rocks and minerals were collected in the caves. In the limestone First Karst Cave, samples of clays were obtained from filled fissures in the walls, and from partly filled passages. All of the samples were processed in a laboratory. The samples were treated 


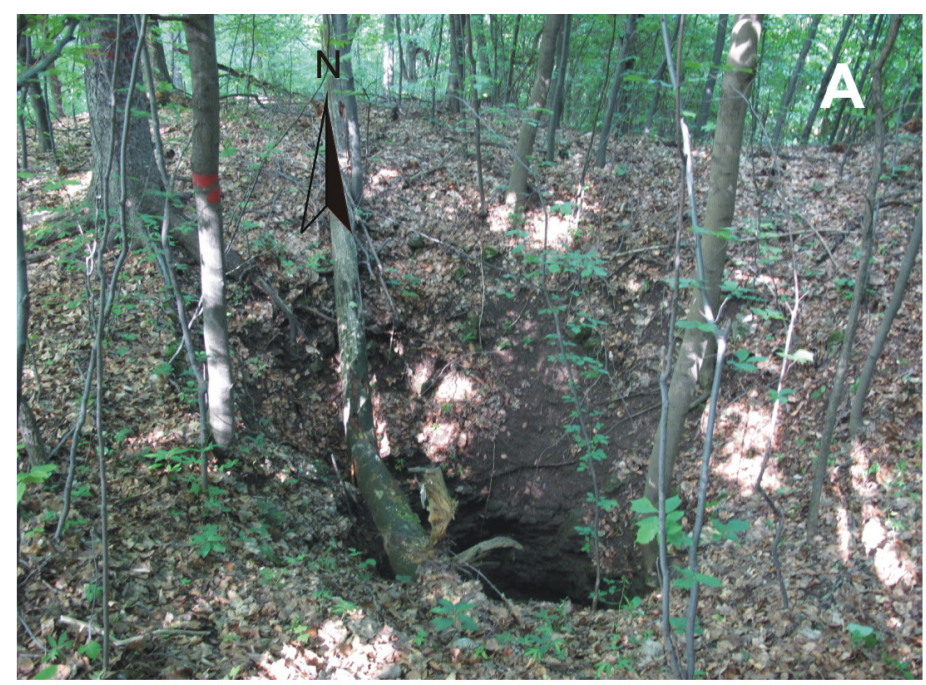

The First Karst Cave

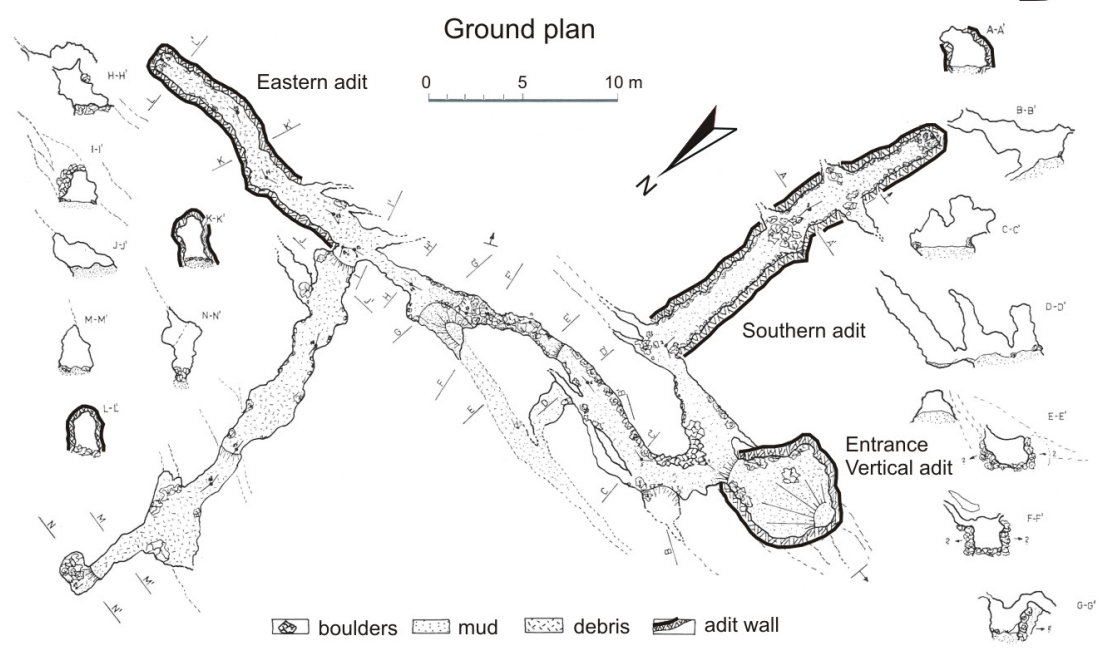

Surveyed by G. Hrabovský, P. Nikel, J. Janeček, P. Burda and K. Ivan, 1984

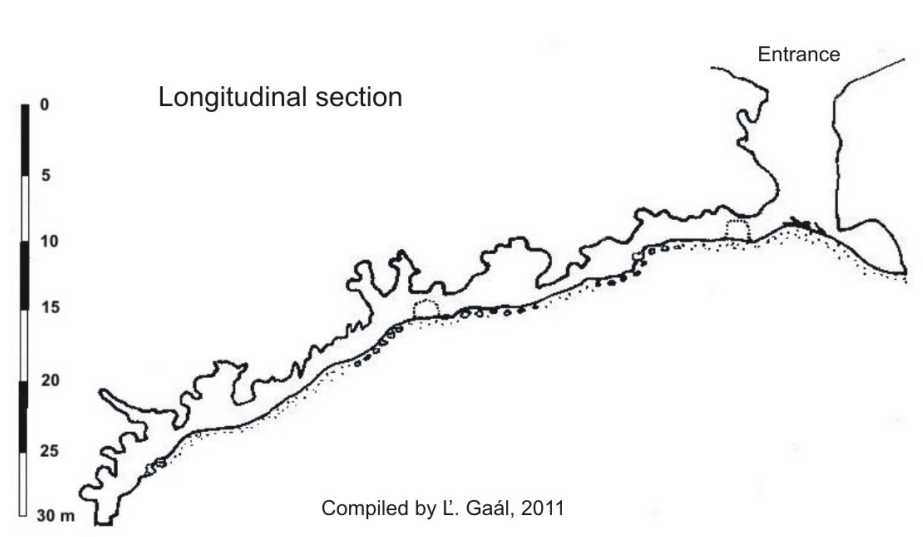

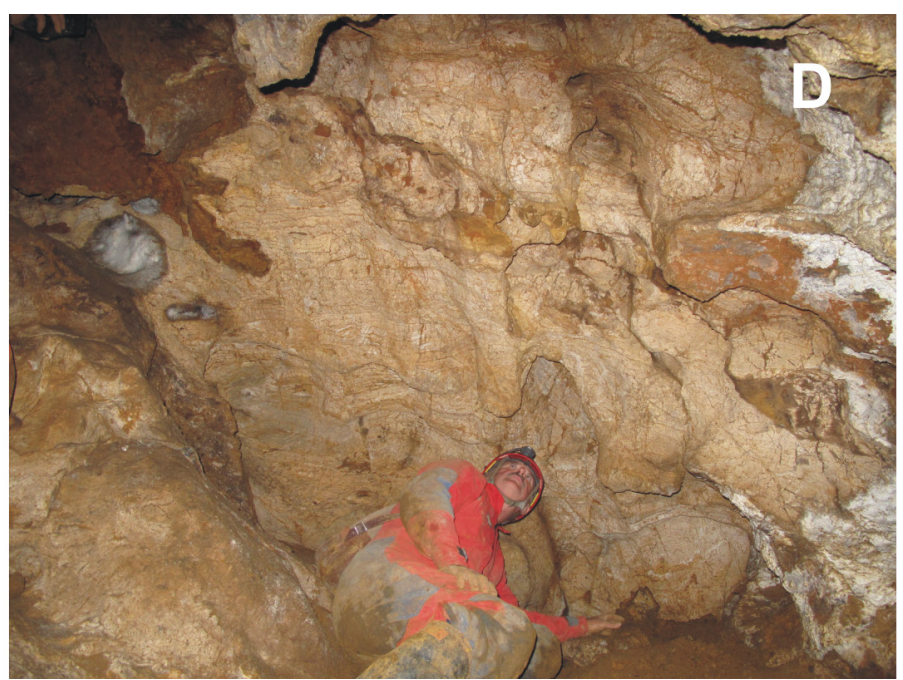

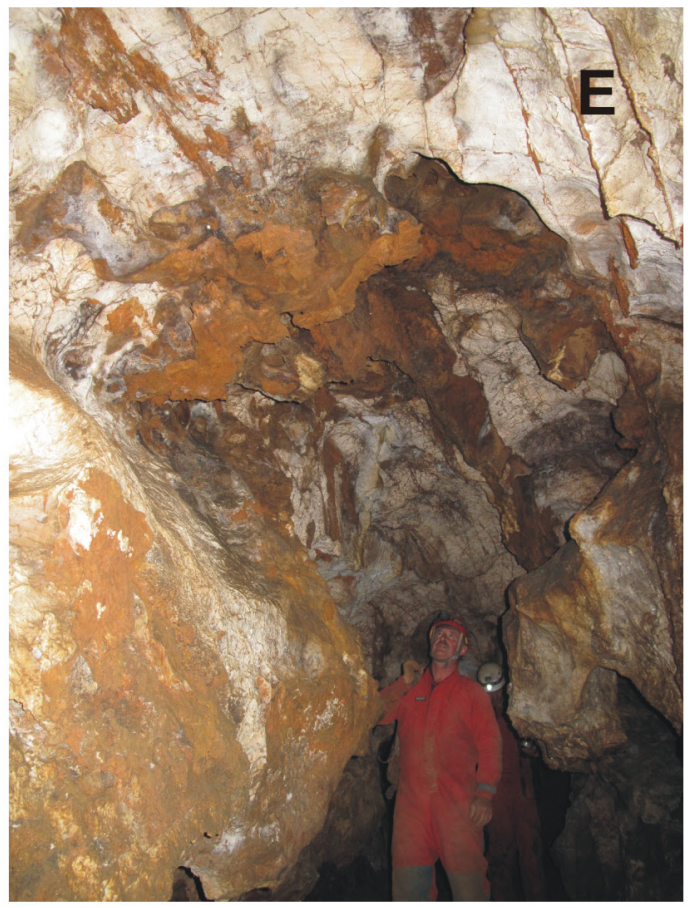

C

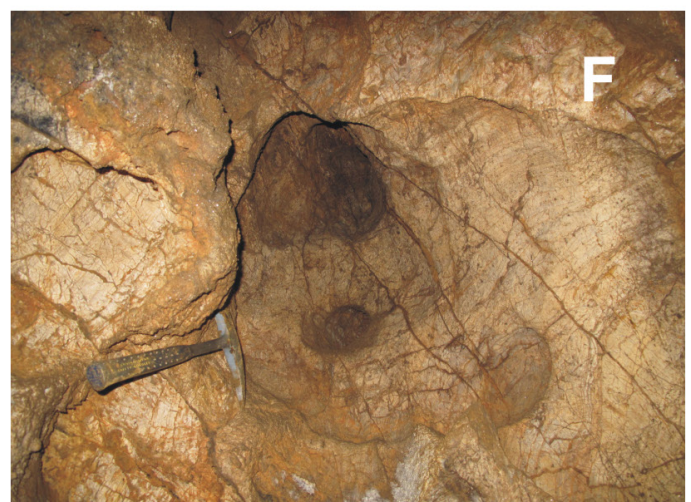

Fig. 3. The First Karst Cave: A) the surface opening of entrance shaft; B) ground plan (from Ivan, 1991); C) simplified longitudinal section through the cave and entrance artificial shaft; D) ceiling spherical depressions; E) morphology of passage in the east-west segment of the cave; F) ceiling pocket (all photos: P. Bella).

with sodium acetate, hydrogen peroxide and sodium dithionite, and the clay fraction $<2 \mu \mathrm{m}$ was separated by sedimentation Samples sedimented on glass slides were analyzed with a Philips PW 1710 diffractometer ( $\mathrm{Cu}-\mathrm{Ka}$ radiation with a graphite monochromator) examining oriented and non-oriented preparates, as well as saturated with ethylene glycol to identify swelling layers. Oriented preparates allow clear identification of layered silicates (Šucha, 2000).
Fluid inclusions in samples from the limestone First Karst Cave were studied using doubly polished wafers ( 200 $\mu \mathrm{m}$ thick) prepared from calcite samples taken from geode-like cavities and cave walls. The observed inclusions were assigned a primary or secondary origin according to the criteria of Roedder (1984). For microthermometric measurements, inclusions grouped into assemblages of primary fluid inclusions (in the sense of Goldstein \& Reynolds, 1994) have 

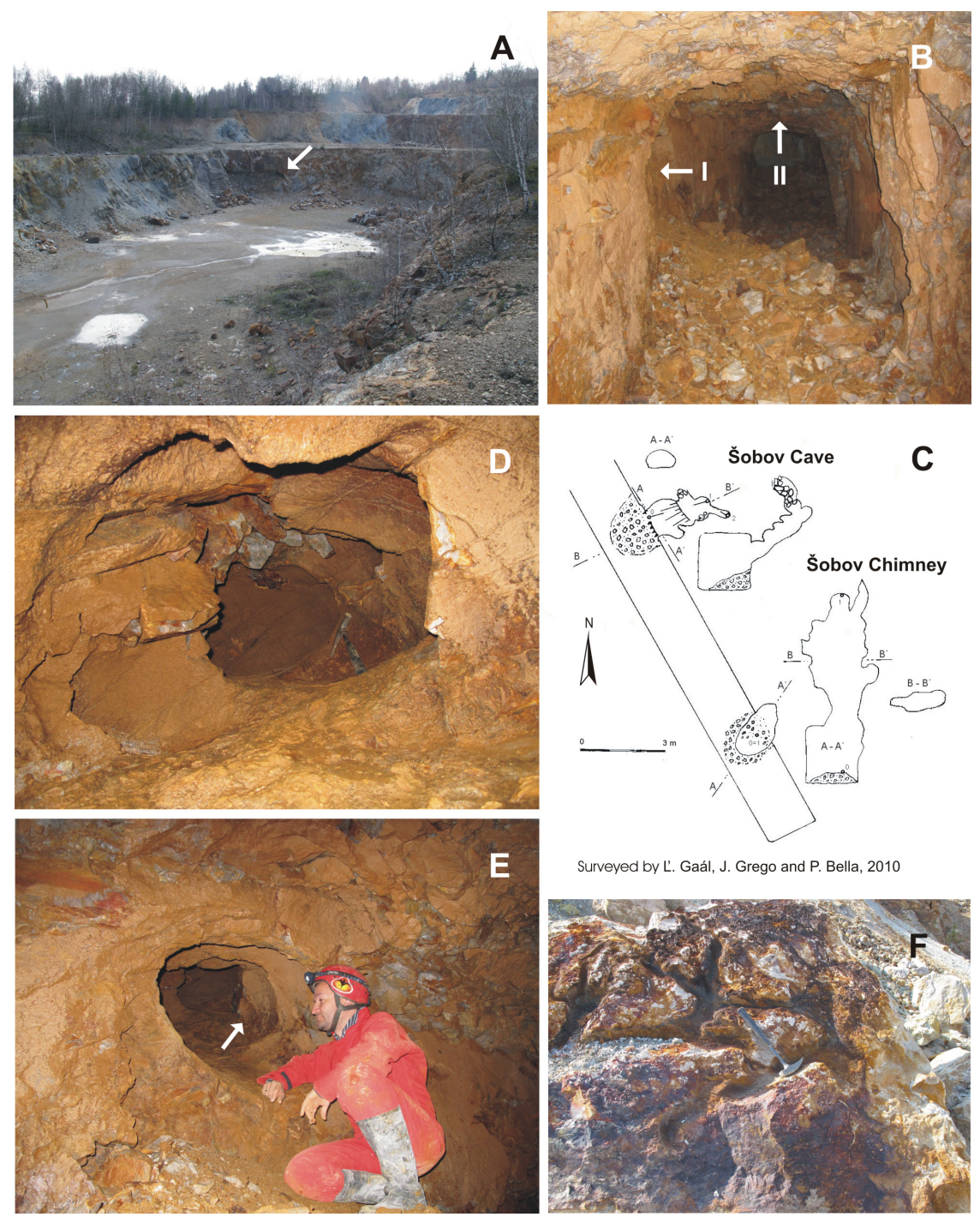

Fig. 4. Caves and channels in the Šobov silicite quarry: A) Šobov quarry (arrow points to the opening of exploration mine adit); B) exploration mine adit with openings of Šobov Cave (I) and Šobov Chimney (II); C) plan of Šobov Cave and Šobov Chimney; D) rising chain of cupola-like forms of the Šobov Cave; E) wall asymmetrical depressions in the lower part of the Šobov Cave; F) small channels deepened into metasomatic silicites along fractures (all photos: P. Bella).

been preferably used. However, due to the limited number of clear fluid inclusion assemblages in the studied material some individual primary inclusions have been also used for microthermometry. Primary origin of fluid inclusions was indicated by random distribution of inclusion assemblages or individual fluid inclusions in calcite grains. Inclusions aligned on 3D planes cutting across the grains were avoided due to their probable secondary origin. The thermometric behavior of fluid inclusions was studied on a Linkam THMSG-600 heating-freezing stage at the State Geological Institute of Dionýz Štúr, Bratislava, Slovakia. The equipment was calibrated with natural fluid inclusions with pure $\mathrm{CO}_{2}\left(-56.6^{\circ} \mathrm{C}\right)$, pure water $\left(0^{\circ} \mathrm{C}\right)$ and inorganic standards $\left(\mathrm{K}_{2} \mathrm{Cr}_{2} \mathrm{O}_{7}, 371^{\circ} \mathrm{C}\right)$. The precision and accuracy of the microthermometric measurements, based on standard calibration procedures, is estimated as $\pm 0.2^{\circ} \mathrm{C}$ for the freezing runs and $\pm 3^{\circ} \mathrm{C}$ for the heating runs. Salinity estimates are based on the last melting temperatures of ice in the system NaCl- $\mathrm{H}_{2} \mathrm{O}$ (Bodnar, 1993). Fluid inclusions in large quartz crystals from caverns in the Šobov silicite quarry were studied by Oružinský and Hurai (1985).
Stable carbon and oxygen isotope composition of carbonates was measured on an isotope ratio mass spectrometer MAT253 (Thermo) coupled through a continuous flow interface using the automated gas preparation and introduction system Gasbench. Samples of carbonate were micro-drilled from polished rock sections, sealed in borosilicate glass vials, flushed by helium and reacted for 24 hours with phosphoric acid at $26^{\circ} \mathrm{C}$, using the method of McCrea (1950). Each analytical run was calibrated using series of two working standards regularly scattered between samples. Measured $\delta^{18} \mathrm{O}$ and $\delta^{13} \mathrm{C}$ values of carbonates are reported in permil relative to $\mathrm{PDB}$, while calculated $\delta^{18} \mathrm{O}$ of water are relative to SMOW.

\section{RESULTS}

\section{Structural-tectonic control and morphology of caves}

Two main linear segments of the First Karst Cave (in ground plan; Fig. 3B) are developed along east- and northoriented, steeply-dipping, crossing faults. These faults were fundamental controlling factors for epithermal mineralization and speleogenesis in basement carbonates of the Stiavnica stratovolcano. Both the northern and western side adits (Fig. 3B) were dug along mineralized veins that intersect the cave passage. These are mainly carbonate veins dipped to $280^{\circ}-285^{\circ}$ at $60^{\circ}-70^{\circ}$. In some places, the veins are filled with Fe-oxyhydroxides and goethite (ochre). The orientation of faults and mineralized veins in the cave corresponds to the orientation of faults of the Hodruša-Štiavnica horst.

Probably, the First Karst Cave is the fragment of a larger three-dimensional cave system. Several smaller spherical hollows that were encountered during the excavation of the northern adit are geode-like cavities (in sense of Audra et al., 2009a). Other geodes and geode-like cavities, visible in some cave walls, were intersected and integrated into the main cave passage during the main development phase of the cave. Numerous small cupolas, ceiling pockets and holes, upward-convex arches, and oval chimneys (Figs. 3C to $3 \mathrm{~F}$ ) occur in the main cave passage. The diameter of the spherical cavities in the ceiling mostly ranges from 30 to $50 \mathrm{~cm}$. The chain of coalesced cupolalike forms and upward-convex arches that extends from the lower to upper part of the cave indicates that water circulated upward in the past. Rising wall channels with asymmetrical dissolution depressions are on some steep cave walls and below some ceiling spherical forms, and indicate ascending water flow. The vertical conduit in the lowest part of the cave resembles a feeder (in sense of Klimchouk, 2007) 
through which fluids had been rising into the cave. These features are indentical with morphological indicators of hypogene or hydrothermal caves (see Klimchouk, 2007; Audra et al., 2009b; and others). The original outlet from the upward-leading main cave passage onto the surface was probably enlarged by miners (remnants of solutional cavities are visible in the lower part of the entrance artificial shaft). Besides, several small natural cavities and caves with spongework morphology (e.g. Voštinová Cave), probably genetically connected with the studied cave, occur near the upper edge of the entrance artificial shaft. Other possible cave openings to the surface were filled and covered by slope sediments or destroyed by slope processes during younger landform development.

The Šobov Cave is a steeply inclined chimney with side cavities that are blind cupolas. Ascending flow of thermal fluids is indicated by a rising chain of cupolalike forms and large asymmetrical depressions in silicite walls (Fig. 4D and 4E). These speleogens are similar to transitional wall and ceiling features seen in hypogene limestone caves. The Šbov Chimney is controlled by an obvious NNE-oriented vertical tectonic fracture. Steep to vertical fractures in both Šobov caves controlled the ascending flow of thermal fluids. Smaller channels deepened into metasomatic silicites along fractures have been observed in other parts of the Šbov quarry (Fig. 4F). The morphology of these caves indicates their hypogene or hydrothermal speleogenesis.

\section{Cave deposits and their mineralogy}

Distinct macroscopic features of hydrothermal alteration as a silicified bedrock and carbonate rocks replaced by high Fe silicites occur in the First Karst Cave (Fig. 5A). Porous silicites of red color are common in cave passages and small side cavities in recrystallized host carbonates. Cave floors are mostly covered by brown clay sediments (Fig. 5B). The host rock of the cave is massive pinkish-gray marble, correlative with Middle Triassic limestones and dolostones of the Fatricum unit. The isotopic composition of the host rock is homogenous across dimensions of the cave, with $\delta^{13} \mathrm{C}$ ranging between 1.1 and $2.8 \%$ and $\delta^{18} \mathrm{O}$ between -23.1 and $-18.7 \%$.

Intensively hydrothermally altered, light yellowgreen friable rock also occurs on cave walls (Fig. 5D). Fissures and side cavities in the lower part of the cave are partially filled by very fine-grained sediments with alternating layers of yellow-ochre, brown and black color (Fig. 5E). These sediments were locally redistributed and deposited in stagnant water conditions within the karstified carbonates. There are no stratigraphic or morphologic indicators of fluvial erosion and transport in these accumulations.

Results of the XRD analysis show that brown clayey material (Sample no. 1, Fig. 5B) contains relatively high content of quartz and small quantity of carbonates. In the clay fraction we detected several layered silicates, mostly smectite and kaolinite (Fig. 6A). Minerals of the illite group (for simplicity illite) are present in trace amounts. The light yellow- green friable rock (Sample no. 2, Fig. 5D) contains predominately illite with minor kaolinite (Fig. 6B), and there is a relatively high content of calcite and quartz. Illite does not contain expandable layers (no change in XRD maxima after a saturation with ethylene glycol). The half-width of the first basal reflection is very low (about $0.2^{\circ} 2 \theta$ ), indicating a high ordering in relatively coarse illite crystals (Fig. 6C). According to the dominant coloration, finegrained layered sediments (Sample no. 3, Fig. 5E) can be separated into three subsamples consisting of yellow-ochre, brown and black material. The

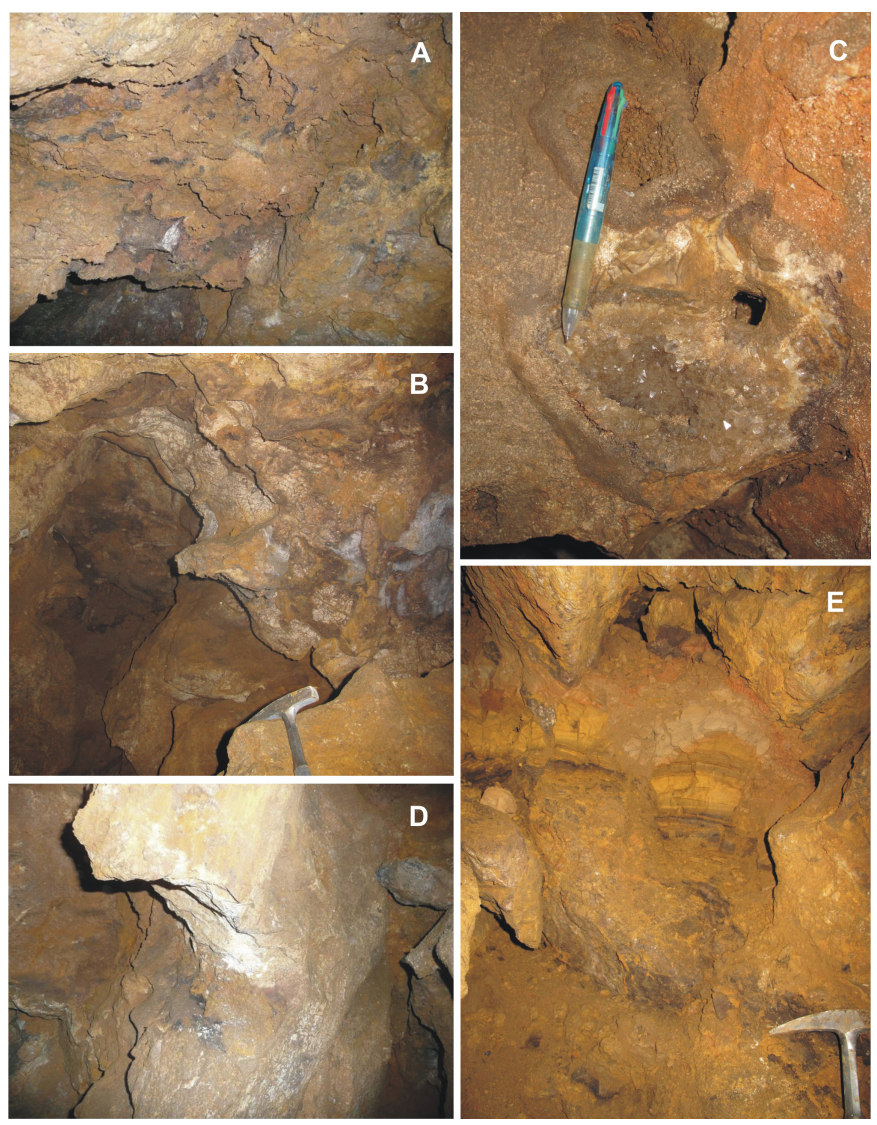

Fig. 5. Altered rocks and deposits in the First Karst Cave: A) carbonate rocks replaced by silicites with high Fe content (photo: V. Šucha); B) brown clay material infilling the bottom of entrance shaft and floor of cave passages (photo: P. Bella); C) large calcite crystals in hydrothermally altered rocks (photo: P. Bella); D) light yellow-green altered and disintegrated rock (photo: V. Šucha); E) redeponed material with alternating layers of yellow-ochre, brown and black color (photo: P. Bella).

subsamples were analyzed separately. The yellowochre and black colored samples have the same mineral composition; they are dominantly formed by goethite (Fig. 6D). The black coloration of some thin goethite layers cannot be explained by differences in mineral composition, but may be caused by an admixture of manganese. Fine-grained sediments of brown color have a mineral composition almost the same as brown clayed sediments on the floor of cave passages.

Three generations of secondary carbonate deposits were recognized:

I) Geode cavities filled with druses of scalenohedral calcite of pale brown, pinkish to white colour up to $4 \mathrm{~cm}$ long (Fig. 5C). The drusy aggregates are grown on an Mn-pigmented dark brown rim 

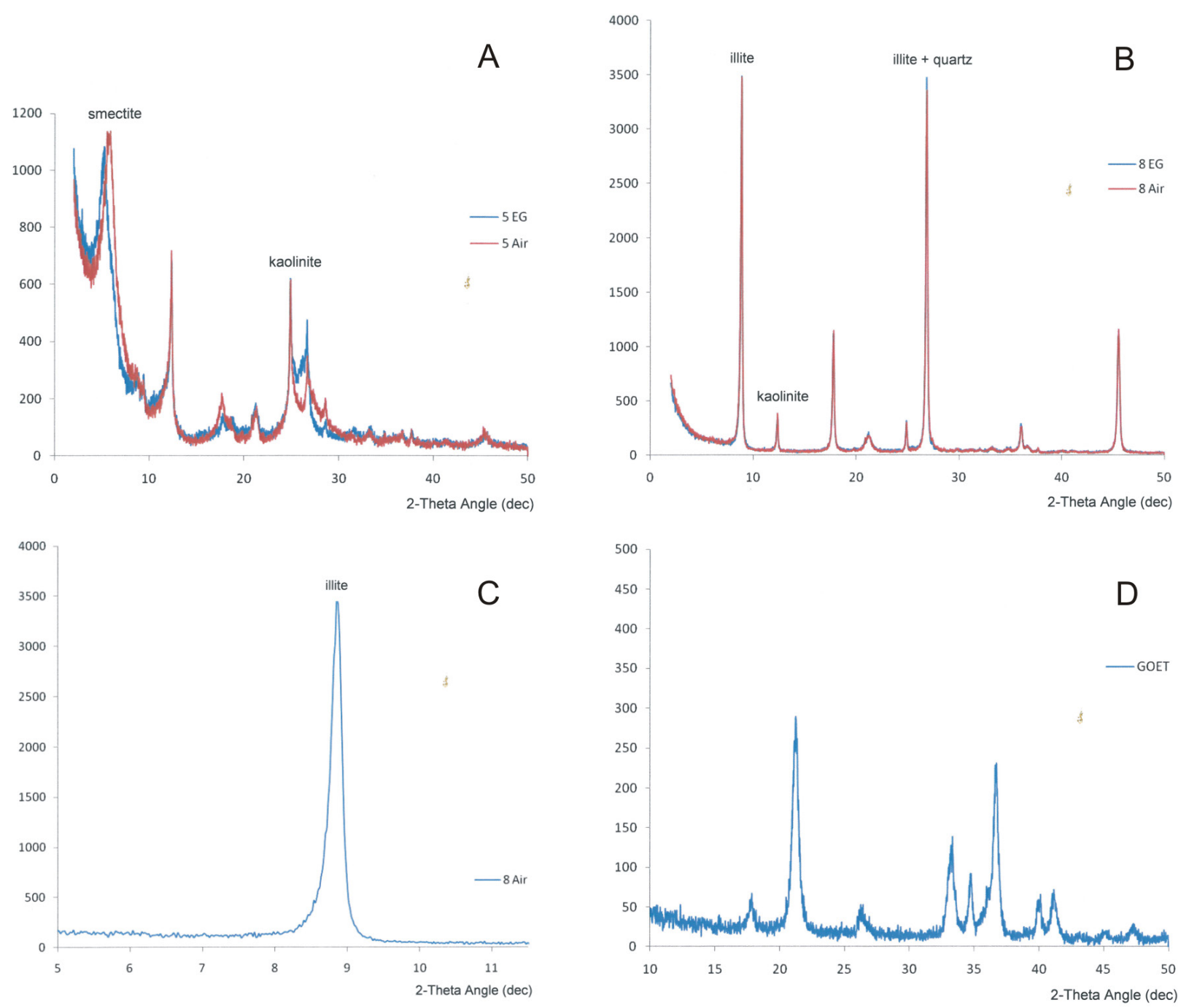

Fig. 6. XRD records of clays from the First Karst Cave: A) XRD record of clay fraction from brown clay material in the natural state (AIR) and after its saturation by ethylene glycol (EG); B) XRD record of clay fraction from light yellow-green friable rock on cave walls in the natural state and after its saturation by ethylene glycol; C) XRD record of the first basal reflex of illite from yellow-green friable rock that denotes its very low half-width $\left(0.2^{\circ} 2 \theta\right)$; D) powder XRD record of goethite (GOET) from fine sediments of yellowochre and black color.

of host marble, representing an alteration zone formed by mineralizing fluid. Typical thickness of this transition zone is from 5 to $20 \mathrm{~mm}$.

II) White laminated crust, locally overgrowing scarce calcite rhombs, patched by nests of prismatic aragonite needles. It covers present walls of main cave passage, truncating geodes and their mineralization (generation I). The thickness of the calcite crust ranges from 1 to $8 \mathrm{~mm}$. Aragonite needles are up to $40 \mathrm{~mm}$ in length. The crust is usually grown on a pale, $3-10 \mathrm{~mm}$ thick alteration zone in host marble or geode mineralization. The generation II is believed to be coeval with main cave formation, its secondary carbonates have been deposited towards the termination of cave formation.

III) Dripstones, flowstones and soda straws of white color, deposited as the latest carbonate mineralization in the cave and oldest adit.

Superposition and cross-cutting relationships of these three generations are shown on Fig. 7 .

Fluid inclusion microthermometry was performed on two samples of calcite, representing generations I and II of the First Karst Cave. Generation III did not contain fluid inclusions suitable for this method.
Microthermometry of primary fluid inclusions hosted in generation I calcite showed a relatively broad range of homogenization temperatures (Th) from 115 to $279^{\circ} \mathrm{C}$ (Figs. 8 and 9), however most of the data were in range from 115 to $168^{\circ} \mathrm{C}$ (mean value $137^{\circ} \mathrm{C}$ ). Higher values of homogenization temperatures of some inclusions probably result from necking down of inclusions that was observed to affect some other inclusions in the analysed sample. All analysed fluid inclusions showed ice melting temperatures $\left(\mathrm{Tm}_{\text {ice }}\right)$ in range from -0.1 to $+0.2^{\circ} \mathrm{C}$, which shows the presence of very little salts dissolved in the fluids ( 0 wt $\%$ $\mathrm{NaCl}$ eq.), indicative of predominance of meteoric component in the source water. The positive values of ice melting temperatures are most likely related to the limited accuracy of stage calibration $\left( \pm 0.2^{\circ} \mathrm{C}\right)$ rather than metastability of ice on heating.

Primary fluid inclusions in generation II calcite also showed a broad range of Th values from 112 to $199^{\circ} \mathrm{C}$ (Fig. 9), with most of the data in range from 143 to $169^{\circ} \mathrm{C}$ (mean value $153^{\circ} \mathrm{C}$ ). Again, the highest Th values are most likely related to stretching of some inclusions on heating. Most measured $\mathrm{Tm}_{\text {ice }}$ values were close to $0^{\circ} \mathrm{C}\left(-0.1\right.$ to $\left.+0.2^{\circ} \mathrm{C}\right)$, indicative of pure water ( $0 \mathrm{wt} \% \mathrm{NaCl}$ eq.), but lot of inclusions showed 
decreased values down to $-1.3^{\circ} \mathrm{C}$, corresponding to salinities of $2.2 \mathrm{wt} \% \mathrm{NaCl}$ eq. Increased salinities show slight positive correlation with corresponding homogenization temperatures (Fig. 9), which can be interpreted as mixing with a hydrothermal fluid containing small amount of magmatic component.

Stable $\mathrm{C}$ and $\mathrm{O}$ isotope measurements focused on three generations of secondary carbonate fills.
Figure 7 shows the relationship of carbonate fills to the host rock and the alteration zones. Both oxygen and carbon isotope delta values show very large spans. Most notable are distinct isotope shifts across both alteration zones, towards lighter carbon in generations I and II, and heavier oxygen in generation II. Ranges of isotope compositions are summarized in Table 1 and graphically represented in Fig. 7.

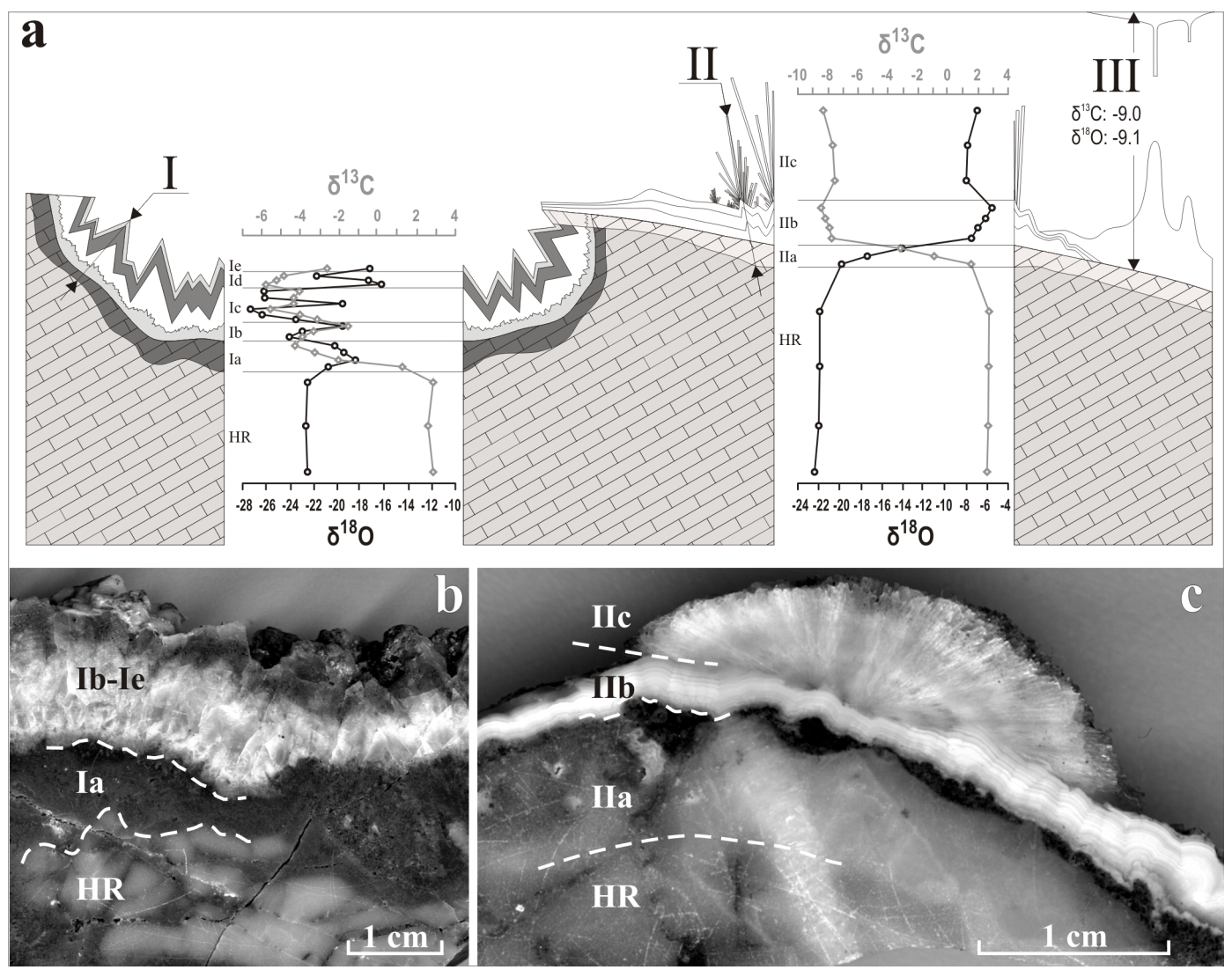

Fig. 7. Schematic sketch (a) and close-up photographs (b, c) of secondary carbonate fills. I, II, and III labels indicate generations/alteration events as in Table 1. Stable $\mathrm{C}$ and $\mathrm{O}$ isotope values are plotted in profiles from intact host rock through alteration zones to subsequent mineral fills. Relative chronology of the stages I, II and III is established by their truncation and superposition.

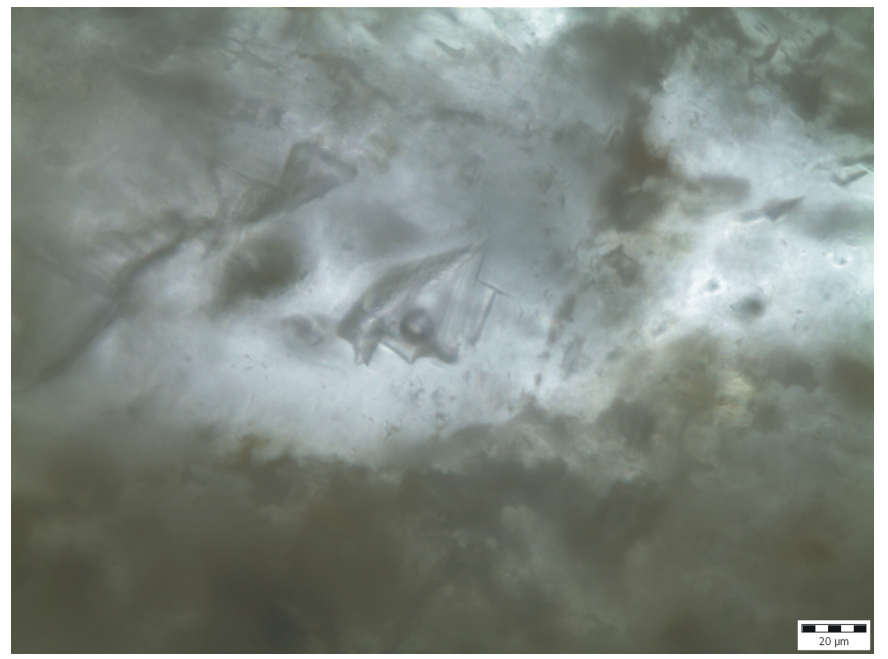

Fig. 8. Typical primary fluid inclusion hosted in a calcite crystal from the First Karst Cave (photo: P. Koděra). Inclusion contains liquid water with contraction bubble (salinity 0 wt\% $\mathrm{NaCl}$ eq., homogenization temperature $\left.165^{\circ} \mathrm{C}\right)$.
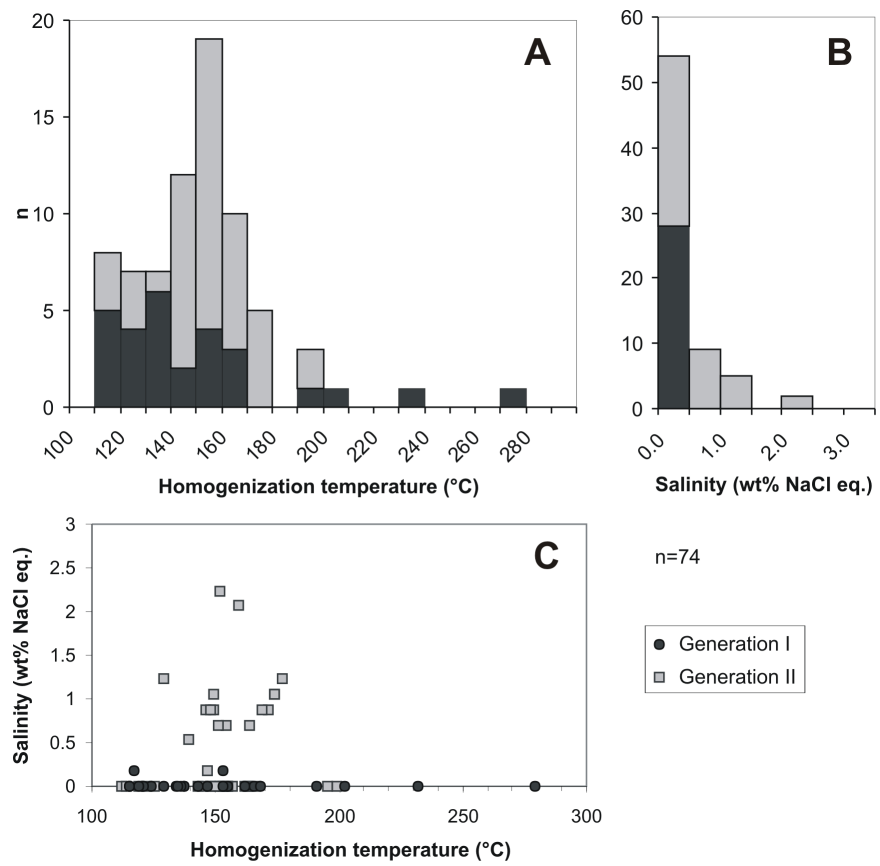

$n=74$

- Generation I

$\square$ Generation II

Fig. 9. A) Histograms of homogenization temperatures (Th) and B) salinities of primary fluid inclusions in two generations of calcite from the First Karst Cave; C) Salinity vs. Th diagram, showing input of hydrothermal fluids other than pure meteoric origin, corresponding to major range of Th values of generation II calcite. 
Table 1. Ranges of isotope compositions of the host rock and three generations of secondary cave carbonates (labelling corresponds to zones sketched in Fig. 7).

\begin{tabular}{|l|l|c|c|}
\hline Zone & \multicolumn{1}{|c|}{ Host rock, cave deposits } & $\mathbf{\delta}^{\mathbf{1 3}} \mathbf{C}(\%$ ) & \multicolumn{1}{c|}{$\mathbf{\delta}^{\mathbf{1 8}} \mathbf{O}(\%)$} \\
\hline HR & host marble & 1.0 to 2.9 & -24.0 to -20.4 \\
\hline Ia & outer brown alteration zone of host marble & $+1.3 \rightarrow-4.4$ & -18.4 to -20.7 \\
\hline Ib & pinkish drusy calcite & $-3.9 \rightarrow-1.5$ & $-24.1 \rightarrow-19.6$ \\
\hline Ic & white drusy calcite & -3.1 to -5.5 & -19.6 to -27.3 \\
\hline Id & brown drusy calcite & -4.0 to -5.5 & -16.2 to -26.1 \\
\hline Ie & latest white drusy calcite & -2.6 & -17.2 \\
\hline IIa & pale alteration zone in host marble & $1.5 \rightarrow-3.2$ & $-19.9 \rightarrow-14.6$ \\
\hline IIb & calcite rhombs covered by laminated crust & $-7.7 \rightarrow-8.5$ & $-7.6 \rightarrow-5.6$ \\
\hline IIc & needle crystals of aragonite & $-7.5 \rightarrow-8.3$ & $-8.0 \rightarrow-7.0$ \\
\hline III & late flowstones and soda straws & -7.9 to -10.4 & -8.4 to -10.4 \\
\hline
\end{tabular}

Note: Ranges of isotope delta values are indicated by „ $\rightarrow$ “ where a distinct trend exists from older to younger laminae, or by „to" where a trend is absent.

\section{INTERPRETATION AND DISCUSSION}

\section{Hydrothermal speleogenesis in basement carbonates of the stratovolcano}

The carbonate host rocks of the First Karst Cave correlate with marine Middle Triassic limestones. Marine isotope signature of carbon is roughly preserved ( 1.0 to $2.9 \%$ ) while that of oxygen is totally obliterated, being more than 20\% depleted against Middle Triassic values (-5 to 0\%o) (Veizer et al., 1999; Korte et al., 2005). Apparent recrystallization of rock and large scale alteration of the original oxygen isotope composition suggest equilibration with a large and penetrative water reservoir at elevated temperatures. Unfortunately the isotope composition of the circulating water remains unknown due to lack of indicators of metamorphic grade in the marble.

Isotope compositions of waters depositing calcite of both generations I and II may be calculated from isotope compositions of calcites at homogenization temperatures of their fluid inclusions, using fractionation factors of O'Neil et al. (1969) and Ohmoto and Rye (1979) for fractionation of oxygen between calcite and $\mathrm{H}_{2} \mathrm{O}$ and carbon between calcite- $\mathrm{CO}_{2}$, respectively. At given temperatures, $\mathrm{CO}_{2}$ is assumed as dominant carbon bearing species in the fluid.

For generation I, with calcite composition $\mathrm{\delta}^{18} \mathrm{O}=-27.3$ to $-16.2 \%$ and $\delta^{13} \mathrm{C}=-5.5$ to $-1.5 \%$, and temperatures between 115 and $168^{\circ} \mathrm{C}$ with mean at $137^{\circ} \mathrm{C}$, equilibrium water has $\delta^{18} \mathrm{O}-13.4$ to $+2.5 \%$ o and equilibrium $\mathrm{CO}_{2}$ has $\delta^{13} \mathrm{C}-8.7$ to $-2.3 \%$. Using mean temperature yields ranges $\delta^{18} \mathrm{O}-11.3$ to $0.2 \%$ o and $\delta^{13} \mathrm{C}-7.6$ to $-3.6 \%$. Light oxygen isotope values probably reflect substantial meteoric component in fluids. However, the presence of heavier oxygen of some analyses may reflect participation of a minor magmatic component in hydrothermal fluids and/or oxygen isotope exchange of heated meteoric waters with volcanic rocks in the vicinity of the cave.

In generation II calcite rhombs and crusts have composition $\delta^{18} \mathrm{O}=-7.5$ to $-5.6 \%$ and $\delta^{13} \mathrm{C}=-8.5$ to $-7.7 \%$, and fluid inclusion temperature range from 143 to $169^{\circ} \mathrm{C}$ with median at $153^{\circ} \mathrm{C}$. Water in equilibrium with calcite at this conditions would have $\delta^{18} \mathrm{O}+9.6$ to $+13.4 \%$ o and $\delta^{13} \mathrm{C}-10.3$ to $-8.5 \%$, and using mean temperature the ranges are $\delta^{18} \mathrm{O}+10.3$ to $+12.3 \%$ and $\delta^{13} \mathrm{C}-9.9$ to $-9.1 \%$. The source of fluid may be meteoric water strongly modified by isotope exchange with rockforming minerals during deep circulation.

Solutional shapes of cavities - both small-scale geodes and large-scale main passage - with secondary carbonates suggest, that the fluids at certain point in their evolution turned from corrosive to depositing, probaby due to $\mathrm{pH}$ increase. Close after this "switch", the temperature and isotope composition of depositing fluids were probably not far from former corrosive fluids, responsible for cavity formation.

The hydrothermal origin of the First Karst Cave is evidenced by irregular spherical morphologies sculptured by rising thermal water, fluid inclusions in calcite crystals, hydrothermal alteration of host rocks and clays of hydrothermal origin composed variably of smectite-kaolinite and goethite.

Mineral association and paleotemperature data show that hydrothermal processes were probably active in several phases (Table 2). A multiphase dissolution of carbonates is documented by the remains of several partially denuded fills in older geodes, geode-like cavities and ceiling hollows that are now integrated into larger, younger cupola-like cavities and main cave passage.

Hydrothermal phases of cave development consists of dissolution of carbonates by fluids of variable temperatures. Fluid inclusions hosted in large calcite crystals of the zone Ic-Id, also in geode-like cavities (Fig. 6), indicate crystallization temperatures in range from 115 to $170^{\circ} \mathrm{C}$. Primary fluid inclusions in generation II calcite indicate crystallization temperatures in range from 112 to $180^{\circ} \mathrm{C}$. The smectite-kaolinite and goethite mineral associations probably formed at temperatures less than 100 to $150^{\circ} \mathrm{C}$ (see McDowell \& Elders, 1980; Reyes, 1990; Šucha et al., 1993; Šucha, 2000). The occurrence of smectite indicates a low-acid to neutral environment with pH 5-7, while the occurrence of kaolinite is linked mainly with solutions with low $\mathrm{pH}$ values between 2-4 (Giese, 1988; Lahodny-Sarc et al., 1993).

Quartz crystals in fissures, exposed by the cave, originated from hot fluids with temperatures probably of at least $200^{\circ} \mathrm{C}$, as indicated by fluid inclusion data from vein quartz in this ore field (Julényová, 1996; Lexa \& Koděra, 2010). The illite mineral association, contained in the light yellow-green friable rock on cave walls, is a typical product of hydrothermal alteration of 
Table 2. Schedule of the development phases of the First Karst Cave.

\begin{tabular}{|c|c|c|c|}
\hline Development phases & Morphology & \multicolumn{2}{|c|}{ Cave deposits } \\
\hline $\begin{array}{l}\text { Hydrothermal phase I (115 to } \\
170^{\circ} \mathrm{C} \text {, predominantly heated } \\
\text { meteoric waters) }\end{array}$ & geodes and geode-like cavities & $\begin{array}{l}\text { calcite crystals } \\
\text { and drusy calcite } \\
\text { (generation I) }\end{array}$ & \\
\hline $\begin{array}{l}\text { Hydrothermal phase II ( } 112 \text { to } \\
180^{\circ} \mathrm{C} \text {, heated meteoric waters } \\
\text { mixed with a hydrothermal fluid } \\
\text { containing small amount of } \\
\text { magmatic component) }\end{array}$ & $\begin{array}{l}\text { main cave passage with cupolas, } \\
\text { ceiling pockets and holes (the } \\
\text { enlargement of geodes and geode- } \\
\text { like cavities and their integration } \\
\text { into the main cave passage, the } \\
\text { fault zone with illite mineral } \\
\text { association and quartz crystals } \\
\text { exposed by the cave) }\end{array}$ & $\begin{array}{l}\text { crust and crystals of } \\
\text { calcite and aragonite } \\
\text { (generation II) }\end{array}$ & $\begin{array}{l}\text { smectite-kaolinite } \\
\text { and goethite mineral } \\
\text { associations }\end{array}$ \\
\hline $\begin{array}{l}\text { Post-hydrothermal phreatic } \\
\text { phase (probably meteoric waters) }\end{array}$ & - & \multicolumn{2}{|c|}{$\begin{array}{l}\text { truncation and partial dissolution of older } \\
\text { carbonate deposits, redistribution and } \\
\text { deposition of clayey sediments in stagnant } \\
\text { water conditions }\end{array}$} \\
\hline $\begin{array}{l}\text { Post-hydrothermal vadose phase } \\
\text { (meteoric waters) }\end{array}$ & - & \multicolumn{2}{|c|}{$\begin{array}{l}\text { dripstones, flowstones and soda straws formed } \\
\text { from seeping meteoric waters (generation III) }\end{array}$} \\
\hline
\end{tabular}

rocks. The thickness of coherent diffracting domains without expanding interlayers indicates temperature of hydrothermal fluids close to $300^{\circ} \mathrm{C}$ (see Eberl et al., 1998; Šucha, 2000). The origin of quartz crystals and illite mineral association has been connected with the hydrothermal origin of adjacent large epithermal vein system (before the formation of the cave).

Hydrothermal processes responsible for the origin of the First Karst Cave were most likely part of a complex extensive hydrothermal system forming hydrothermal ore deposits $3 \mathrm{~km}$ from the cave. The hydrothermal deposits evolved during various stage of the development of the Štiavnica stratovolcano in Badenian to Sarmatian time (Lexa et al., 1999; Lexa, 2001). The deposits include pre-caldera stage skarn-porphyry systems (Sklené Teplice - Vydričná Valley and Kozi Hill) and post-caldera stage Ag-Au epithermal vein systems (Windischleuten vein). The Sklené Teplice system is believed to have caused silicification of carbonates north of the cave at Bukovec, while the Windischleuten vein system south of the cave is related to the horst uplift in the center of the caldera. The northwest part of the Windischleuten vein encroaches into Triassic limestones, dolomites and siliceous sediments of the Velký bok Group (Lexa et al., 1997), in which the First Karst Cave is developed.

Fluid inclusion petrography and microthermometry and clay mineralogy of both systems are similar and partially overlap with data obtained for the cave. Silicified zones from Bukovec contain fluid inclusions with salinities from 1.0 to $5.6 \mathrm{wt} \% \mathrm{NaCl}$ eq. and two different ranges of homogenization temperatures (Julényová, 1996). The upper range $\left(200\right.$ to $\left.240^{\circ} \mathrm{C}\right)$ corresponds to major crystallization of quartz, followed by a lower temperature, less significant crystallization stage $\left(150\right.$ to $\left.180^{\circ} \mathrm{C}\right)$. Paleofluids from the Windischleuten vein system have not yet been studied. However, there exist fluid inclusion data from a similar Au-Ag vein systems in the neighboring areas of Hodruša and Vyhne (Lexa \& Koděra, 2010). Here, fluids precipitated vein filling minerals during several stages, while salinities did not significantly exceed
$5 \mathrm{wt} \% \mathrm{NaCl}$ eq. and homogenization temperatures ranged from 150 to $310^{\circ} \mathrm{C}$, depending on the stage.

Calculated oxygen isotope data of water in equilibrium with generations I and II calcite from the cave can be also compared to published isotope data from skarn-porphyry and Ag-Au epithermal systems in the central zone of the Štiavnica stratovolcano. Data from Sklené Teplice and from Windischleuten are not available, however, data can be compared to similar coeval systems in this ore district. Hydrothermal fluids at the skarn-porphyry system Vysoká-Zlatno showed mostly strong magmatic signature $\left(-4.2\right.$ to $+12.5 \%$ o $\left.\delta^{18} \mathrm{O}\right)$ (Koděra et al., 2010), but Ag-Au epithermal system at Všechsvätých $\mathrm{Ag}-\mathrm{Au}$ vein showed significantly lighter oxygen isotope signature $\left(-3.1\right.$ to $1.1 \%$ o $\delta^{18} \mathrm{O}_{\text {fluid }}$, indicative of significant meteoric component in the fluids (Koderra et al., 2007). Data from calcites from the First Karst Cave $\left(-13.4\right.$ to $+2.5 \%$ o $\delta^{18} \mathrm{O}_{\text {fluid }}$ for generation I and +9.6 to $+13.4 \%$ o $\delta^{18} \mathrm{O}_{\text {fluid }}$ for generation II) overlap with data from both neighbouring systems.

In conclusion, neither fluid inclusion nor stable isotope data made clear which of the two neighboring systems was responsible for the origin of the First Karst Cave. However, the presence of vein mineralisation intersecting the cave indicates that the post-caldera epithermal system is slightly more likely.

In both hydrothermal environments the low salinity of fluids can be attributed to dilution of magmatichydrothermal fluids by mixing with meteoric waters during their ascent from depth (Julényová, 1996; Lexa \& Koderra, 2010). Thermal waters rising along deep faults were saturated with $\mathrm{CO}_{2}$ from magmatic and volcanic activity. Their solutional aggressiveness could be maintained, renewed or enhanced by decreasing temperature (the inverse relationship between calcite solubility and temperature, even at constant $\mathrm{CO}_{2}$ levels; see Palmer, 1991) and mixing of waters of contrasting chemistry (in sense of Bögli, 1964), mainly at shallow depths (see Dublyansky, 2000 and others). The post-magmatic hydrothermal dissolution of carbonates was responsible for the development the First Karst Cave. During the formation of this 
cave Middle Triassic host carbonates in the area were covered by fractured volcanic or volcanoclastic rocks of unknown thickness.

After hydrothermal phases with the most intense dissolution of carbonates and the dominant enlargement of underground passages and cavities, older carbonate deposits in the cave were truncated and partially dissolved in phreatic conditions. Clayey sediments were redeponed and deposited in slowly moving to stagnant water (Table 2). Finally, downcutting of the stream valley extended below the elevation of the cave and the current vadose development phase began. During the youngest vadose phase, water from precipitation that seeps into the cave has not altered older corrosion forms on the bedrock walls and ceilings.

In the area surrounding the First Karst Cave, hydrothermal processes are still active. Hot geothermal waters $\left(33\right.$ to $\left.35^{\circ} \mathrm{C}\right)$ within the hydrogeological structure near Sklené Teplice Spa are connected to Triassic carbonates and ascend along two crossing faults. One fault is NNE-oriented and bounds preTertiary rocks of the Hodruša-Štiavnica horst from the west. The second is a transverse fault oriented WNW that bounds the Bukovec block (Remšík et al., 2001 and others).

Analogous examples of hydrothermal speleogenesis associated with metallogenesis of ore deposits (caves originated by a post-magmatic dissolution of metamorphosed carbonates) are known from the Romanian Carpathians (Mârza \& Silvestru, 1988; Onac, 2002; Onac \& Damm, 2002; and others). Hydrothermal or mixed hydrothermal/vadose origin of skarn hosted caves of the Băița metallogenic district in the Bihor Mountains is related to a deep-seated Upper Cretaceous granitic pluton (Onac, 2002). In the NE part of Greece, the early genesis of Maronia Cave is related to an andesite intrusion during Miocene that generated ascending thermal fluid circulation in Middle Eocene numulitic limestones causing development of hypogenic solution voids (Vaxevanopoulos \& Melfo, 2010).

\section{Hydrothermal speleogenesis in metasomatic silicites}

In the two investigated caves in the Šobov silicite quarry, spherical morphology sculptured by ascending fluids, hydrothermal alteration of host rocks and the occurrence of quartz crystals are distinct indicators of hydrothermal origin. Speleogenesis in the Šobov silicites was caused by hydrothermal processes during the pre-caldera phase of development of the Štiavnica stratovolcano in Upper Badenian.

The Šbov paleohydrothermal system is a typical hydrothermal system associated with high temperature $\left(>200^{\circ} \mathrm{C}\right)$ magmatic fluids of high oxidation state (well known in Economic Geology as „high sulfidation“ or "acid sulfate" systems), related here to the emplacement of a diorite intrusion in the footwall of the altered andesite (Lexa et al., 1999) (Fig. 10). Hydrothermal systems of this type form in two stages (Sillitoe, 1989; Hedenquist \& Arribas, 1999). The first (major) stage is related to upflow of magmatic fluids containing $\mathrm{HCl}, \mathrm{SO}_{2}$ and $\mathrm{HF}$ that within the central upflow column condense into the hydrothermal system, forming $\mathrm{H}_{2} \mathrm{~S}$ and $\mathrm{H}_{2} \mathrm{SO}_{4}$ and a very acidic (pH 1-3) solution (Rye et al., 1992). This acidic fluid is capable of leaching most of the major elements from the host rock, resulting in vuggy textures. Highly siliceous rock is either porous and vuggy or massive and dense, the latter largely due to silicification of the residual quartz developed due to leaching (Simmons et al., 2005). Cavernous and metasomatic silicites occur in the center of the system, surrounded by argillized rocks affected by advanced argillic style of alteration (including alunite, pyrophyllite, dickite and quartz). The origin of caverns and caves in the Šobov area is probably related to this early stage of leaching. Acids reacted here with andesite, altering it to metasomatic silicite that is locally cavernous, especially in its upper part. The mushroom-shaped body of metasomatic silicite is surrounded by a zone rich in illite, pyrophylite, and pyrite (Uhlik \& Šucha, 1997; Uhlik et al., 2001). The presence of pyrophylite indicates a temperature of more than $270^{\circ} \mathrm{C}$, while the

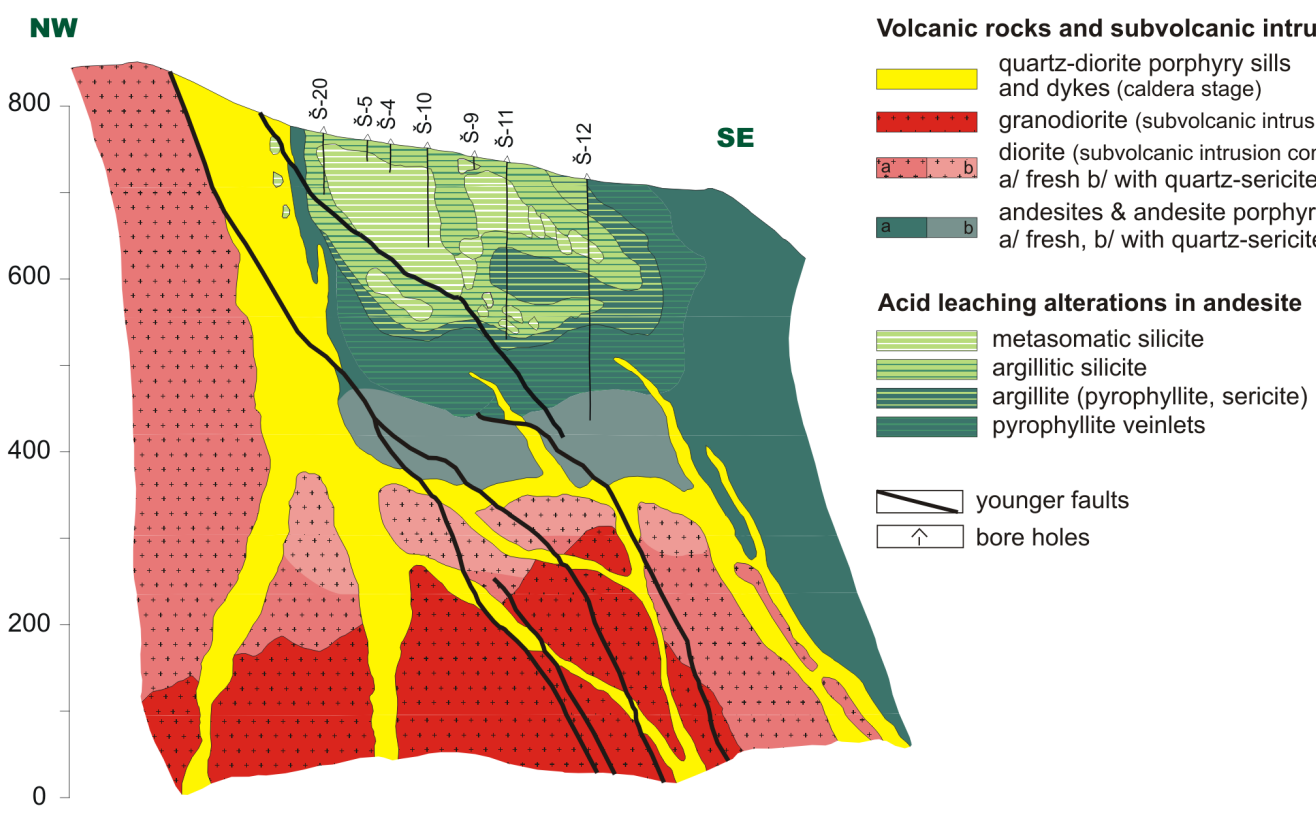

Fig. 10. Section of the Šobov metasomatic silicite deposit (after Onačila et al., 1995). 
amount of pyrophylite and pyrite decreases with the increasing distance from the silicite body.

The second stage is caused by penetration of more neutral fluids, possibly with a meteoric component. In the Šobov hydrothermal system these fluids were responsible for precipitation of quartz crystals in cavities and local opal/chalcedony veins in upper part of the system. Oružinský and Hurai (1985) published data on microthermometry of fluid inclusions in quartz crystals from several cavities in the quarry. Homogenization temperatures ranged here from 200 to $300^{\circ} \mathrm{C}$ (with a maximum between 250 to $270^{\circ} \mathrm{C}$ ) and salinities were lower than $2.7 \mathrm{wt} \% \mathrm{NaCl}$ eq., with major components $\mathrm{NaCl}$ and $\mathrm{KCl}$. These data indicate a minimum depth of origin $660 \mathrm{~m}$ beneath the paleosurface (Oružinský \& Hurai, 1985). One independent low-temperature pulse at $150^{\circ} \mathrm{C}$ was also detected by Oružinský and Hurai (1985). In deeper parts, these more neutral fluids may be responsible for minor disseminated metal mineralization (Lexa et al., 1999). Cavities in metasomatic silicites were filled by minerals precipitated from flowing and cooling fluids. Later, these fills were washed out by posthydrothermal waters.

From a genetic and geochemical viewpoint the described deep-seated speleogenesis in metasomatic silicites of the Šbov area differs from the cave origin in siliceous rocks by weathering dissolution process called "arenisation" and subsequent mechanical erosion caused by underground flowing waters. This lithologically specific cave origin is initiated by hydration of quartz or by incongruent dissolution of silicate minerals controlled by the $\mathrm{pH}$ of the associated solution. The dissolution of quartz by meteoric waters along joints in silicates, or along crystal boundaries, leads to weathering of silicite into soft "neosandstone", and eventually into sand (Martini, 1979, 2000, 2004; Jennings, 1983; Piccini \& Mecchia, 2009; Wray, 2010; Mecchia et al., 2014; and others). The presence of gypsum and pyrophyllite led Zawidzki et al. (1976) to propose that some caves in quartz-sandstones of the "tepui" table mountains in Venezuela were the result of a low-grade metamorphic event with related rising hydrothermal fluids possibly enriched in $\mathrm{H}_{2} \mathrm{~S}$. But local minor variations of the $\mathrm{S}$ isotopic signature may be related to additional minor sources of reduced sulphur from peat bogs and decomposed vegetation. In these settings, there is no need to invoke hydrothermal events or oxidation of sulphides in the host rock for the formation of gypsum (Sauro et al., 2014).

\section{CONCLUSION}

The First Karst Cave is a remarkable example of a hydrothermal limestone cave associated with Miocene volcanic and magmatic processes in central Slovakia. The cave originated in hydrothermally altered rocks, characterized by cupolas, ceiling pockets and holes, chimneys, geode-like cavities with idiomorphic calcite crystals and clays of hydrothermal origin. Mineral associations indicate two phases of hydrothermal activity within the cave formation when smectite, kaolinite, goethite and secondary carbonates of generations I and II were formed. The origin and development of this cave was multiphase and multiprocess, related to multiphase dissolution of carbonates. This conclusion is based on remains of partially denuded fills in older geodes and geode-like cavities cut by larger and younger ceiling hollows and main cave passage. The main phases of intensive dissolution of carbonates by hydrothermal fluids resulted in development of hypogene cavities and passages. This was followed by a post-hydrothermal phreatic phase, and finally vadose phase that did not made striking changes in the original cave morphology.

The caves in the Šobov quarry are associated with magmatic-hydrothermal activity. They are a rare occurrence of hydrothermal caves in metasomatic silicites and are the only known hydrothermal silicite caves in Slovakia. Their origin is related to deep-seated hydrothermal processes related to a diorite intrusion in the northern part of central zone of the Štiavnica stratovolcano during its pre-caldera evolution phase in Upper Badenian.

\section{ACKNOWLEDGEMENTS}

We acknowledge the field assistance of D. Trcka, J. Grego, P. Staník and J. Šurka, and consultations of J. Lexa, J. Hók and M. Chovan. Many thanks to two reviewers and the editor for their useful comments and suggestions. The study is result of the projects of the Scientific Grant Agency of the Ministry of Education, Science, Research and Sport of the Slovak Republic and the Slovak Academy of Sciences (VEGA) No. 1/0030/12,1/0430/15,1/0560/15 and 2/0193/15.

\section{REFERENCES}

Audra P., Mocochain L., Bigot J.-Y. \& Nobécourt J.-C., 2009a - Hypogene cave patterns. In: Klimchouk A.B. $\&$ Ford D.C. (Eds.), Hypogene speleogenesis and karst hydrogeology of Artesian Basins. Ukrainian Institute of Speleology and Karstology, Simferopol, Special Paper, 1, p. 17-22.

Audra P., Mocochain L., Bigot J.-Y. \& Nobécourt J.-C., 2009b - Morphological indicators of speleogenesis: hypogenic speleogens. In: Klimchouk A.B. \& Ford D.C. (Eds.), Hypogene speleogenesis and karst hydrogeology of Artesian Basins. Ukrainian Institute of Speleology and Karstology, Simferopol, Special Paper, 1, p. 23-32.

Bakalowicz M.J., Ford D.C., Miller T.E., Palmer A.N. \& Palmer M.V., 1987 - Thermal genesis of dissolution caves in the Blach Hills, South Dakota. Geological Society of America Bulletin, 99 (6): 729-738.

http://dx.doi.org/10.1130/0016-7606(1987)99 $\leq 729$ :TGODCI>2.0.CO;2

Bella P., Gaál L. \& Grego J., 2010 - Hydrothermal quartzite caves in the Šobov quarry near Banská Štiavnica. Slovenský Kras, 48 (1): 19-30. (Slovak and English).

Bella P., Gaál L., Šucha V., Koděra P. \& Grego J., 2011a Hydrothermal caves in the Štiavnické vrchy Mountains. Aragonit, 16 (1-2): 59-60. (Slovak).

Bella P., Šucha V., Gaál L. \& Koděra P., 2011b - The First Karst Cave in the Štiaunické vrchy Moutains, Central Slovakia - hydrothermal speleogenesis in basement carbonates of Miocene stratovolcano. Slovenský Kras, 49 (1): 5-21. (Slovak and English). 
Bodnar R.J., 1993 - Revised equation and table for determining the freezing point depression of $\mathrm{H}_{2} \mathrm{O}-$ $\mathrm{NaCl}$ solutions. Geochimica et Cosmochimica Acta, 57: 683-684. http://dx.doi.org/10.1016/0016-7037(93)90378-a

Bögli A., 1964 - Mischungkorrosion, ein Beitrag zur Verkarstungsprobleme. Erdkunde, 18: 83-92. http://dx.doi.org/10.3112/erdkunde.1964.02.02

Chernyshev I.V., Konečný V., Lexa J., Kovalenker V.A., Jelen̆ S., Lebedev V.A. \& Goltsman Y.V., 2013 - K-Ar and $\mathrm{Rb}-\mathrm{Sr}$ geochronology and evolution of the Stiaunica Stratovolcano (Central Slovakia). Geologica Carpathica, 64 (4): 327-351.

http://dx.doi.org/10.2478/geoca-2013-0023

Dubljanskij J.V., 1990 - Particularities of the development and modelling of hydrothermal karst. Nauka, Novosibirsk, 151 p. (Russian and English).

Dublyansky Y.V., 2000 - Dissolution of carbonates by geothermal waters. In: Klimchouk A.B., Ford D.C., Palmer A.N. \& Dreybrodt W. (Eds.), Speleogenesis. Evolution of karst aquifers. National Speleological Society, Huntsville, p. 158-159.

Dublyansky V.N., 2000 - Hydrothermal speleogenesis - Its settings and peculiar features. In: Klimchouk A.B. Ford D.C., Palmer A.N. \& Dreybrodt W. (Eds.), Speleogenesis. Evolution of karst aquifers. National Speleological Society, Huntsville, p. 292-297.

Eberl D.D., Nuesch R., Šucha V. \& Tsipursky S., 1998 Measurement of fundamental illite particle thickness by $X$-ray diffraction using PVP-10 intercalation. Clays and Clay Minerals, 46 (1): 89-97.

http://dx.doi.org/10.1346/CCMN.1998.0460110

Ford D.C. \& Williams P.W., 1989 - Karst geomorphology and hydrology. Unwin Hyman, London, Boston, Sydney, Wellington, $601 \mathrm{p}$.

Ford D.C. \& Williams P.W., 2007 - Karst hydrogeology and geomorphology. Wiley, Chichester, $562 \mathrm{p}$. http://dx.doi.org/10.1002/9781118684986

Giese R.F., 1988 - Kaolin minerals: Structures and stabilities. In: Bailey S.W. (Ed.), Hydrous phyllosilicates. Reviews in Mineralogy and Geochemistry, 19, p. 29-66.

Hedenquist J.W. \& Arribas A. Jr., 1999 - The tops and bottoms of high sulphidation epithermal ore deposits. In: Stanley C.J. et al. (Eds.), Mineral deposits: Processes to processing. Balkema, Rotterdam, Brookfield, p. 515-518.

Goldstein, R.H. \& Reynolds, T.J. 1994 - Systematics of fluid inclusions in diagenetic minerals. Society of Sedimentary Geology, SEPM Short Course 31, 199 p.

Ivan K., 1991 - Operational area of the regional speleological group B. Štiavnica. Spravodajca SSS, 21 (1): 24-28. (Slovak).

Jennings J.N., 1983 - Sandstone pseudokarst or karst? In: Young R.W. \& Nanson G.C. (Eds), Aspects of Australian sandstone landscapes. University of Wollongong, Wollongong, Australian and New Zealand Geomorphology Group Special Publication, 1, p. 21-30.

Julényová E., 1996 - Fluid inclusions in silicified zones of the Bukovec Mesozoic complex. Geologické práce, Správy, 101: 77.

Klimchouk A., 2007 - Hypogene speleogenesis: Hydrological and morphogenetic perspective. National Cave and Karst Research Institute, Carlsbad, Special Paper, 1, 106 p.

Klimchouk A.B., 2009 - Principal features of hypogene speleogenesis. In: Klimchouk A.B. \& Ford D.C. (Eds.), Hypogene speleogenesis and karst hydrogeology of Artesian Basins. Ukrainian Institute of Speleology and Karstology, Simferopol, Special Paper, 1, p. 7-15.
Koděra P., Lexa J. \& Fallick A.E., 2010 - Formation of the Vysoká-Zlatno Cu-Au skarn-porphyry deposit, Slovakia. Mineralium Deposita, 45 (8): 817-843. http://dx.doi.org/10.1007/s00126-010-0304-9

Koděra P., Lexa J., Fallick A.E., Wälle M. \& Biroñ A., 2014 - Hydrothermal fluids in epithermal and porphyry Au deposits in the Central Slovakia Volcanic Field. Geological Society, London, Special Publications, 402: 177-206. http://dx.doi.org/10.1144/SP402.5

Koděra P., Lexa J., Konečný P., Ferenc Š., Matło L., Hók J. \& Fallick A.E., 2007 - Source of fluids and genesis of epithermal mineralisation in Neogene volcanites. Unpublished MS Thesis, State Geological Institute of Dionýz Štúr, Bratislava. (Slovak).

Koděra P., Lexa J., Rankin A.H. \& Fallick, A.E, 2005 - Epithermal gold veins in a caldera setting: Banská Hodruša, Slovakia. Mineralium Deposita, 39 (8): 921-943. http://dx.doi.org/10.1007/s00126-004-0449-5

Konečný V. \& Lexa J., 1984 - Geological map of the Central-Slovakian neovolcanites 1:100.000. Geological Institute of Dionýz Štúr, Bratislava.

Konečný V. \& Lexa J., 2001 - Structure and evolution of the Stiavnica stratovolcano. Mineralia Slovaca, 33 (3): 179-196. (Slovak and English).

Konečný V., Lexa J., Halouzka R., Dublan L., Šimon L., Stolár M., Nagy A., Polák M., Vozár J., Havrila M. \& Pristaš J., 1998a - Geological map of the region of Štiavnické vrchy Mts. and Pohronský Inovec Mts. 1:50.000. Geological Survey of the Slovak Republic, Bratislava.

Konečný V., Lexa J., Halouzka R., Hók J., Vozár J., Dublan L., Nagy A., Šimon L., Havrila M., Ivanička J., Hojstričová V., Miháliková A., Vozárová A., Konečný P., Kováčiková M., Filo M., Marcin D., Klukanová A., Liščák P. \& Žáková E., 1998b - Explanation for the geological map of Štiavnické vrchy Mts. and Pohronský Inovec Mts. (Štiavnica stratovolcano). Geological Survey of the Slovak Republic, Bratislava, vol. I. and II., 473 p. (Slovak and English).

Konečný V., Lexa J. \& Hojstričová V., 1995 - The Central Slovakian Neogene volcanic field: a review. Acta Vulcanologica, 7 (2): 63-78.

Konečný V., Lexa J., Šimon L. \& Dublan L., 2001 The neogene volcanism in central Slovakia. Mineralia Slovaca, 33 (3): 159-178. (Slovak and English).

Korte C., Kozur H.W. \& Veizer J., $2005-\delta^{13} C$ and $\delta^{18} \mathrm{O}$ values of Triassic brachiopods and carbonate rocks as proxies for coeval seawater and palaeotemperature. Palaeogeography, Palaeoclimatology, Palaeoecology, 226 (3-4): 287-306.

http://dx.doi.org/10.1016/j.palaeo.2005.05.018

Lahodny-Sarc O., Dragcevic Z. \& Keller W.D., 1993 The hydrothermal synthesis of kaolinite up to $350^{\circ} \mathrm{C}$. In: Murray H., Bundy W. \& Harvey C. (Eds.), Kaolin genesis and utilization. Clay Mineral Society, Special Publication, 1, p. 325-341.

Lexa J., 2001 - Metallogeny of the Štiaunica stratovolcano. Mineralia Slovaca, 33 (3): 203-214. (Slovak and English).

Lexa J. \& Koděra P., 2010 - Assessment of realised geological works oriented to the verification of ore deposit potential in the Banská Štiavnica-Hodruša ore field. Unpublished MS Thesis, State Geological Institute of Dionýz Štúr, Bratislava. (Slovak).

Lexa J., Koděra P., Onačila D., Rojkovičová L., Žáková E. \& Tréger M., 1997 - Complex assessment of prognosticated resources of ore deposits in the area of central zone of the Štiavnica stratovolcano. Unpublished MS Thesis, State Geological Institute of Dionýz Štúr, Bratislava. (Slovak). 
Lexa J., Seghedi I., Németh K., Szakács A., Konečný V., Pécskay Z., Fülöp A. \& Kovacs M., 2010 - NeogeneQuaternary volcanic forms in the Carpathian-Pannonian region: a review. Central European Journal of Geosciences, 2 (3): 207-270. http://dx.doi.org/10.2478/v10085-010-0024-5

Lexa J., Štohl J. \& Konečný V., 1999 - The Banská Stiaunica ore district: relationship between metallogenetic processes and the geological evolution of a stratovolcano. Mineralium Deposita, 34 (5-6): 639-654. http://dx.doi.org/10.1007/s001260050225

Martini J.E.J., 1979 - Karst in Black Reef quartzite near Kaapsehoop, Eastern Transvaal. Annals of the Geological Survey of South Africa, 13: 115-128.

Martini J.E.J., 2000 - Dissolution of quartz and silicate minerals. In: Klimchouk A.B., Ford D.C., Palmer A.N. \& Dreybrodt W. (Eds.), Speleogenesis. Evolution of Karst Aquifers. National Speleological Society, Huntsville, p. 171-174.

Martini J.E.J., 2004 - Silicate karst. In: Gunn J. (Ed.), Encyclopedia of caves and karst sciences. Fitzroy Dearbon, New York, London, p. 649-653.

Mârza I. \& Silvestru E., 1988 - First mention of the hydrothermal karst phenomenon in Romania, associated to the Neogene metasomatic sulfide ore deposits from Rodna Veche. Studia Universitatis Babeş-Bolyai, Geologia-Geographia, 33: 77-81.

McCrea J.M., 1950 - On the isotopic chemistry of carbonates and a paleotemperature scale. The Journal of Chemical Physics, 18: 847-857.

http://dx.doi.org/10.1063/1.1747785

McDowell S.D. \& Elders W.A., 1980 - Authigenic layer silicate minerals in Borehole Elmore1. Salton Sea geothermal deposit field, California, USA. Contributions to Mineralogy and Petrology,74: 293-310. http://dx.doi.org/10.1007/BF00371699

Mecchia M., Sauro F., Piccini L., De Waele J., Sanna L., Tisato N., Lira J. \& Vergara F., 2014 - Geochemistry of surface and subsurface waters in quartz-sandstones: significance for the geomorphic evolution of tepui table mountains (Gran Sabana, Venezuela). Journal of Hydrology, 511: 117-138. http:/dx.doi.org/10.1016/j.jhydrol.2014.01.029

Ohmoto H. \& Rye R.O., 1979 - Isotopes of sulfur and carbon. In: Barnes H.L. (Ed.), Geochemistry of hydrothermal ore deposits, (2 $2^{\text {nd }}$ Ed.). Willey, New York, p. 509-567.

Onac B., 2002 - Caves formed within Upper Cretaceous skarns at Băița, Bihor County, Romania: mineral deposition and speleogenesis. The Canadian Mineralogist, 40 (6): 1693-1703.

http://dx.doi.org/10.2113/gscanmin.40.6.1693

Onac B.P. \& Damm P., 2002 - Preliminary data on the mineralogy of limestone and skarn-hosted caves from Băița (Bihor County, Romania). Studia UBB Geologia, 47 (1): 93-104. http://dx.doi.org/10.5038/1937-8602.47.1.7

Onačila D., Lexa J., Marsina K., Rojkovičová L., Káčer Š., Hojstričová V., Žáková E., Štohl J., Konečný V., Nemčok M., Koděra P., Konečný P., Repčok I., Hurai V., Háber M., Jeleň S., Mat’o L., Sasvári T., Schmidt R., Zvara I. \& Grant T., 1995 - Metallogenetic model and resource assessment of the Śtiavnica stratovolcano central zone. Unpublished MS Thesis, State Geological Institute of Dionýz Štúr, Bratislava. (Slovak).

O‘Neil J.R, Clayton R.N. \& Mayeda T.K., 1969 - Oxygen isotope fractionation in divalent metal carbonates. The Journal of Chemical Physics, 51: 5547-5558. http://dx.doi.org/10.1063/1.1671982

Oružinský V., 1989 - Secondary quartzites of CentralSlovakian nevolcanites. Mineralia Slovaca, 21 (6): 533537. (Slovak and English).
Oružinský V. \& Hurai V., 1985 - Fluid inclusions in secondary quartzites of the Stiavnica stratovolcano. Mineralia slovaca, 17 (5): 415-424. (Slovak and English).

Palmer A.N., 1991 - Origin and morphology of limestone caves. Geological Society of America Bulletin, 103 (1): 1-21. http://dx.doi.org/10.1130/0016-7606(1991) 103<0001:OAMOLC >2.3.CO;2

Palmer A.N., 2007 - Cave Geology. Cave Books, Dayton, 454 p.

Polák S., 1961 - Central-Slovakian dinas quartzites and the perspective of their industry using. Geologický průzkum, 2: 37-39. (Slovak).

Piccini, L. \& Mecchia, M. 2009. Solution weathering rate and origin of karst landforms and caves in the quartzite of Auyan-tepui (Gran Sabana, Venezuela). Geomorphology, 106 (1-2): 15-25.

http://dx.doi.org/10.1016/j.geomorph.2008.09.019

Polák S., 1963 - To the genesis of dinas quartzites deposits on Mt. Šobov near Banská Štiaunica. Geologické práce, Zprávy, 29: 143-155. (Slovak).

Remšik A., Mad’ar D., Konečný V., Král M., Šefara J., Grand T. \& Weis K., 2001 - Geothermal waters of the Banská Stiaunica region and possibilities of their obtaining. Mineralia Slovaca, 33 (3): 243-251. (Slovak and English).

Reyes A.G., 1990 - Petrology of Philippine geothermal system and the application of alteration mineralogy to their assessment. Journal of Volcanology and Geothermal Research, 43 (1-4): 279-309.

http://dx.doi.org/10.1016/0377-0273(90)90057-M

Roedder E., 1984 - Fluid inclusions. Reviews in Mineralogy, Mineralogical Society of America, 12, 644 p.

Rye R.O., Bethke P.M. \& Wasserman M.D., 1992 - The stable isotope geochemistry of acid sulfate alteration. Economic Geology, 87 (2): 225-238.

http://dx.doi.org/10.2113/gsecongeo.87.2.225

Sauro F., Tisato N., De Waele J., Bernasconi S.M., Bontognali T.R.R. \& Galli E., 2014 - Source and genesis of sulphate and phosphate-sulphate minerals in a quartz-sandstone cave environment. Sedimentology, 61 (5): 1433-1451.

http://dx.doi.org/10.1111/sed.12103

Sillitoe R.H., 1989 - Gold deposits in Western Pacific island arcs: The magmatic connection. In: Keays R.R., Ramsay W.R.H. \& Groves D.I. (Eds.), The geology of gold deposits: The perspective in 1988. Economic Geology Monographs, 6, p. 274-291.

Simmons S.F., White N.C. \& John D., 2005 - Geological characteristics of epithermal precious and base metal deposits. In: Hedenquist J.W., Thompson J.F.H., Goldfarb R.J. \& Richards J.P. (Eds.), Economic Geology 100 th anniversary volume 1905-2005. Society of Economic Geologists, Littleton, p. 485-522.

Spötl C., Dublyansky Y., Meyer M. \& Mangini A., 2009 - Identifying low-temperature hydrothermal karst and palaeowaters using stable isotopes: a case study from an alpine cave, Entrische Kirche, Austria. International Journal of Earth Sciences (Geologische Rundschau), 98 (3): 665-676. http://dx.doi.org/10.1007/s00531-007-0263-2

Štohl J., Lexa J., Kaličiak M. \& Bacsó Z., 1994 - Genesis of stockwork base metal mineralizations in the Neogene volcanics of West Carpathians. Mineralia Slovaca, 26 (2): 75-117. (Slovak and English).

Šucha V., 2000 - Clays in geological processes. Vydavatel'stvo UK, Bratislava, 159 p. (Slovak).

Šucha V., Kraus I., Gerthofferová H., Peteš J. \& Sereková M., 1993 - Smectite to illite conversion in bentonites and shales of the East Slovak Basin. Clay Minerals, 28 (2): 243-253.

http://dx.doi.org/10.1180/claymin.1993.028.2.06 
Uhlik P. \& Šucha V., 1997 - Distribution of pyrophyllite in the Šbov deposit and comparison with pyrophyllite from Viglašská Huta deposit (Central Slovakia). Mineralia Slovaca, 29 (1): 73-79. (Slovak and English).

Uhlík P., Šucha V., Madejová J., Puškelová L. \& Šamajová E., 2001 - Clay minerals in the area of the Śtiaunica stratovolcano. Mineralia Slovaca, 33 (3): 287-288. (Slovak).

Vaxevanopoulos M. \& Melfos V., 2010 - Hypogenic features in Maronia Cave, Thrace, Greece. Evidence from morphologies and fluid inclusions. Bulletin of the Geological Society of Greece, 43 (2): 948-957.
Veizer J., Ala D., Azmy K., Bruckschen P., Buhl D., Bruhn F., Carden G.A.F., Diener A., Ebneth S., Goddéris Y., Jasper T., Korte C., Pawellek F., Podlaha O.G. \& Strauss H., $1999-{ }^{87} \mathrm{Sr} /{ }^{86} \mathrm{Sr}, \delta^{13} \mathrm{C}$ and $\delta^{18} \mathrm{O}$ evolution of Phanerozoic seawater. Chemical Geology, 161 (1-3): 59-88. http://dx.doi.org/10.1016/S0009-2541(99)00081-9

Wray R.A.L., 2010 - The Gran Sabana: The world`s finest quartzite karst? In: Migoń P. (Ed.), Geomorphological landscapes of the world. Springer, Dordrecht, p. 79-88.

Zawidzki P., Urbani F. \& Koisar B., 1976 - Preliminary notes on the geology of the Sarisarinama plateau, Venezuela, and the origin of its caves. Boletin de la Sociedad Venezolana de Espeleología, 7: 29-37. 